\title{
Therapeutic Strategies to Increase Human $\beta$-Cell Growth and Proliferation by Regulating mTOR and GSK-3/ $\beta$-Catenin Pathways
}

\author{
Nidhi Rohatgi ${ }^{1}$, Maria S. Remedi ${ }^{2}$, Guim Kwon ${ }^{3}$, Kirk L. Pappan ${ }^{1}$, Connie A. Marshall ${ }^{1}$ and \\ Michael L. McDaniel* ${ }^{*}$
}

\author{
${ }^{I}$ Department of Pathology and Immunology, ${ }^{2}$ Department of Cell Biology and Physiology, Washington University in St. \\ Louis, St. Louis, Missouri, USA and ${ }^{3}$ Department of Pharmaceutical Sciences, School of Pharmacy, Southern Illinois \\ University Edwardsville, Edwardsville, IL, USA
}

\begin{abstract}
This perspective delineates approaches to develop therapeutic strategies to stimulate the proliferative potential of adult human $\beta$-cells in vitro. Previous findings demonstrated that nutrients, through regulation of mTOR signaling, promote regenerative processes including DNA synthesis, cell cycle progression and $\beta$-cell proliferation in rodent islets but rarely in human islets. Recently, we discovered that regulation of the Wnt/GSK-3/ $\beta$-catenin pathway by directly inhibiting GSK-3 with pharmacologic agents, in combination with nutrient activation of mTOR, was required to increase growth and proliferation in human islets. Studies also revealed that nuclear translocation of $\beta$-catenin in response to GSK3 inhibition regulated these processes and was rapamycin sensitive, indicating a role for mTOR. Human islets displayed a high level of insulin resistance consistent with the inability of exogenous insulin to activate Akt and engage the Wnt pathway by GSK-3 inhibition. This insulin resistance in human islets is not present in rodent islets and may explain the differential requirement in human islets to inhibit GSK-3 to enhance these regenerative processes. Human islets exhibited normal insulin secretion but a loss of insulin content, which was independent of all treatment conditions. The loss of insulin content may be related to insulin resistance, the isolation process or culture conditions. In this perspective, we provide strategies to enhance the proliferative capacity of adult human $\beta$-cells and highlight important differences between human and rodent islets: the lack of a nutrient response, requirement for direct GSK-3 inhibition, insulin resistance and loss of insulin content that emphasize the physiological significance of conducting studies in human islets.
\end{abstract}

Keywords: Human $\beta$-cell, mTOR, GSK-3, $\beta$-catenin, proliferation, Exenatide.

Globally, the number of people with diabetes mellitus is expected to rise from the current estimate of 190 to 330 million in the next 20 years [1]. This striking increase suggests that diabetes is now at epidemic proportions and constitutes a significant socioeconomic problem. A marked reduction of $\beta$-cell mass plays an important role in the pathogenesis of both Type 1 (T1DM) and Type 2 (T2DM) Diabetes. Autoimmune-mediated destruction of pancreatic $\beta$ cells results in T1DM with absolute insulin deficiency and constitutes $5-10 \%$ of cases [2]. T2DM is characterized by insulin resistance, as well as $\beta$-cell dysfunction with a relative insulin deficiency and constitutes $90-95 \%$ of cases [3].

There are several forms of insulin and synthetic amylin available for the treatment of T1DM. Various therapeutic agents are used to treat hyperglycemia associated with T2DM that act by increasing insulin secretion, decreasing production of glucose from the liver or increasing insulin sensitization in peripheral tissues. However, these agents are known to lose their efficacy over time, resulting in a loss of glycemic control. The newly available incretin and dipeptidyl peptidase-4 (DPP-IV) drugs have positive effects

\footnotetext{
*Address correspondence to this author at the Department of Pathology and Immunology, Washington University in St. Louis, Campus Box 8118, 660 S. Euclid Avenue, St. Louis, Missouri 63110, USA; Tel: 314-362-7435; Fax: 314-362-4096; E-mail: mmcdaniel@wustl.edu
}

on glucose-dependent insulin secretion [4]. These drugs have also been shown to increase $\beta$-cell proliferation in rodent models. In postnatal human islets their efficacy to stimulate proliferation of $\beta$-cells is yet to be ascertained [5]. However, Movassat et al. have reported the proliferation of human fetal islets when treated with Exendin-4 [6]. In addition, studies in both human and rodent islets using GLP-1 or analogs have also shown anti-apoptotic effects that are necessary to maintain $\beta$-cell mass $[7,8,9]$.

\section{CELLULAR MECHANISMS CONTROLLING $\beta$ - CELL MASS}

Pancreatic $\beta$-cell mass is not firmly set but is regulated by several mechanisms including self-duplication, $\beta$-cell size, neogenesis (new $\beta$-cells from other cell types), and apoptosis [10]. A balance between these mechanisms regulates $\beta$-cell mass. The contribution made by each mechanism is variable, and depends on the stage of life, metabolic demands and animal species. The disruption of this balance results in rapid and marked changes in $\beta$-cell mass. Analyses of the regulatory parameters described above have shown that there is continual loss and renewal of $\beta$ cells throughout life [11,12].

Nutrients, growth factors and secondary messengers through multiple pathways regulate $\beta$-cell growth and proliferation, and there are significant differences in the regulation of these pathways between humans and rodents. 
Important pathways include PI-3K, Akt, mTOR, Wnt, calcineurin/NFAT $[13,14]$ and G-protein coupled receptor $[5,15]$. Growth Hormone (GH), prolactin (PRL) and placental lactogen (PL) are potent growth factors that increase $\beta$-cell mass through the Jak/Stat pathway $[16,17]$. In rodent models, the atrial natriuretic peptide (ANP) [18], HGF [19], PDGF [13], and EGF [20] have also been shown to contribute to increased $\beta$-cell mass. Studies in rodents, have also demonstrated that chronic infusion of elevated glucose results in increased $\beta$-cell mass, through proliferation and/or the neogenesis of $\beta$-cells [21-23]. In addition, $\mathrm{Ca}^{2+}$ and cAMP are important secondary messengers integrating mitogenic pathways in $\beta$-cells.

Although there are multiple pathways involved in $\beta$-cell growth and proliferation, this perspective will focus on two major growth-related pathways, mammalian target of rapamycin (mTOR) and glycogen synthase kinase-3 (GSK3 )/ $\beta$-catenin, that are regulated by nutrients and growth factors. An additional focus will be to identify significant differences that exist between human and rodent islets regarding these two signaling pathways.

\section{SOURCE OF NEW $\boldsymbol{\beta}$-CELLS DURING ADULT LIFE}

Recently, Dor et al. [24] reported the significance of the proliferative capacity of existing adult $\beta$-cells as a source of new $\beta$-cells during adult life [25]. This investigation emphasized by genetic lineage tracing that adult pancreatic $\beta$-cells are formed by self duplication rather than by differentiation of adult stem cells. In similar studies, Teta $e t$ al. [26] employing a novel DNA analog-based lineage tracking technique reported that the growth and regeneration of adult $\beta$-cells did not involve specialized progenitors or stem cells from adult mice in vivo. Rather, adult $\beta$-cells are derived by self-replication from a large pool of mature $\beta$ cells.

In response to the novel observations highlighting the importance of the proliferative capacity of existing adult $\beta$ cells to duplicate [24-28], the goal of our research is to develop therapeutic strategies targeting growth-related signaling pathways to increase adult human $\beta$-cell growth and proliferation while maintaining insulin biosynthesis and secretory function.

\section{mTOR SIGNALING PATHWAY}

mTOR, a member of the phosphatidylinositol 3-kinase (PI3K)-related kinase (PIKK) family of protein kinases, is conserved from yeast to humans [29,30]. Fig. (1) depicts schematically pathways involved in mTOR signaling. mTOR regulates cell growth and metabolism by functioning as part of two distinct protein complexes, mTOR complex 1 (mTORC1) and mTOR complex 2 (mTORC2). mTORC1 contains the kinase, target of rapamycin (mTOR, also known as FRAP1), raptor (regulatory associated protein of mTOR), G $\beta$ L (also known as LST8), Deptor and PRAS-40 and regulates protein synthesis in mammals [31]. The phosphorylation of eukaryotic initiation factor $4 \mathrm{E}$ binding protein 1 (4EBP1) by mTOR results in the release of eukaryotic initiation factor 4E (eIF-4E) and allows its

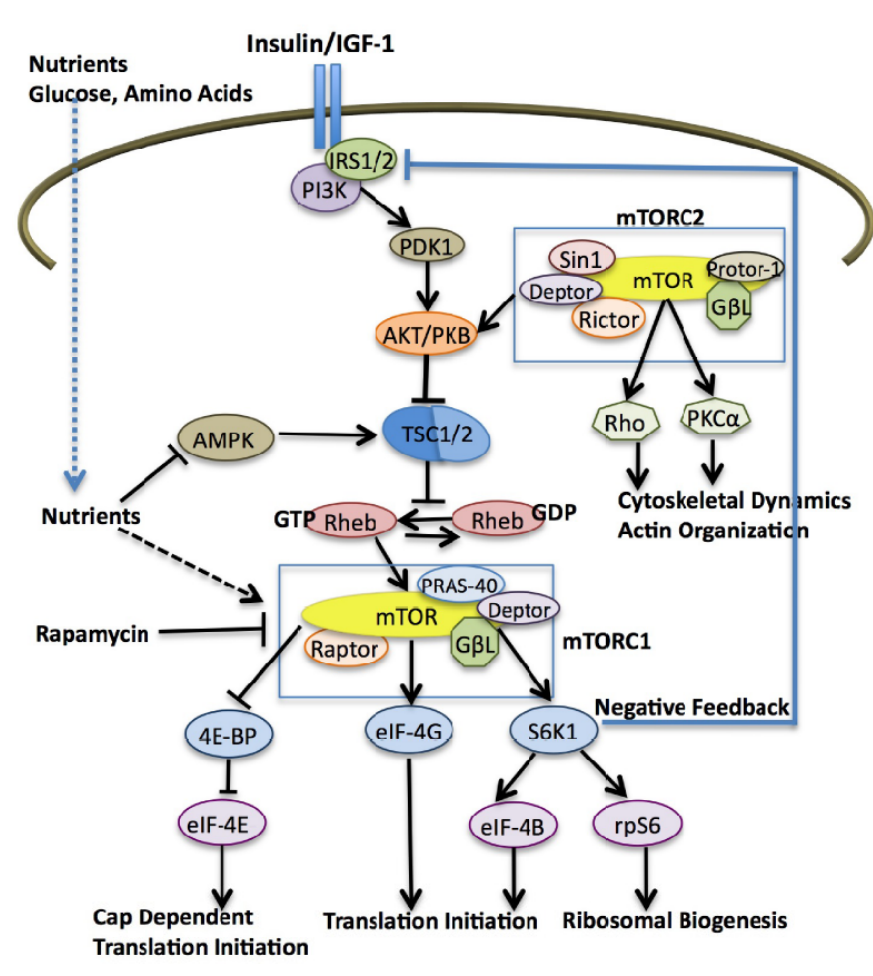

mTOR Pathway

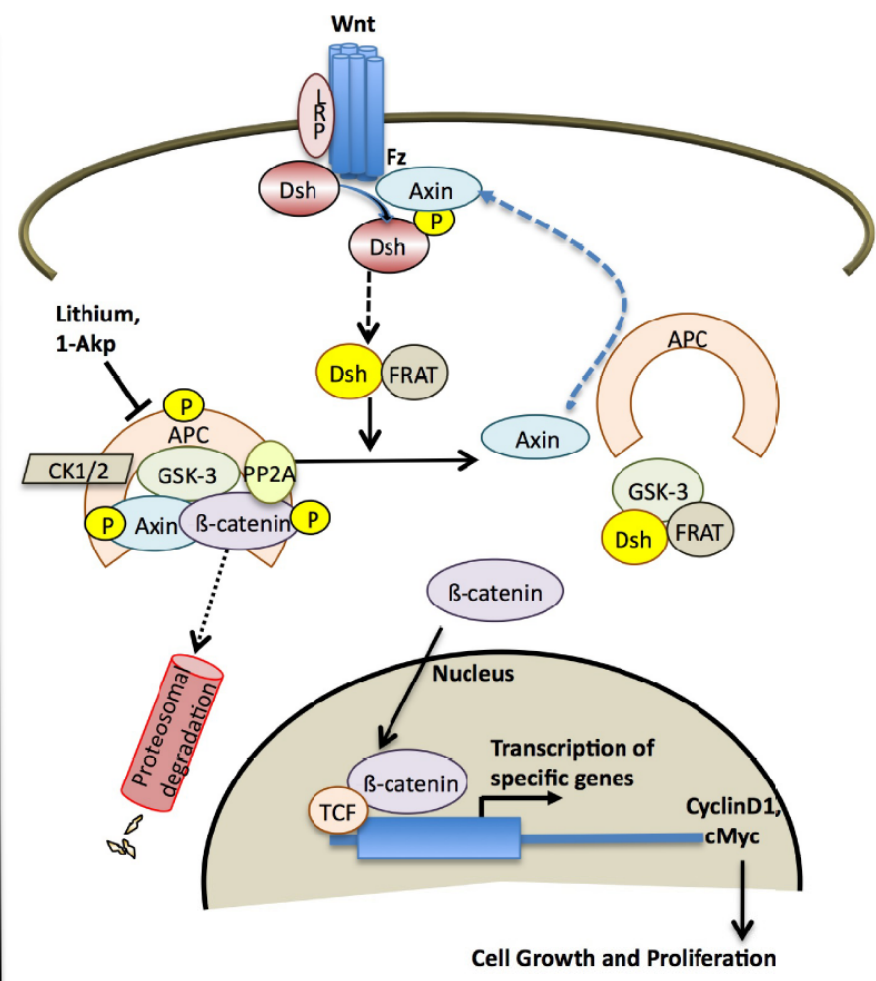

Wnt/GSK-3/ $\beta$-Catenin Pathway

Fig. (1). General schematic of the mTOR and Wnt signaling pathways. 
participation in the initiation of cap-dependent mRNA translation. mTOR-mediated phosphorylation of ribosomal protein S6 kinase 1 (S6K1, also known as p70s6k) results in the phosphorylation of ribosomal protein S6 (rpS6), that correlates with the translation of mRNAs encoding both ribosomal proteins and translational elongation factors [32]. mTORC1 signaling is potently and specifically inhibited by rapamycin that prevents the phosphorylation of these translational regulators $[32,33]$.

mTORC2 consists of mTOR, Rictor, mSin1, G $\beta \mathrm{L}$, Protor-1 and Deptor [34,35] and elicits distinct biological functions from mTORC1 due to its functional activators. mTORC2 is responsible for phosphorylation of S473, one of the two key residues required for full activation of Akt [36]. mTORC2 also regulates actin cytoskeletal polarization [37] and reorganization [38,39]. mTORC2 directly phosphorylates S6K1, and serum- and glucocorticoidinducible kinase (SGK) (not shown in figure) and is largely insensitive to rapamycin [40].

Insulin and growth factors exert their effects through the receptor tyrosine kinases and the down stream docking proteins, insulin receptor substrates, IRS1 and 2, that in turn activate the class I phosphatidylinositide-3 kinase (PI-3K) signaling pathway. At the membrane, class I PI-3K produces the second messenger, phosphatidylinositol $(3,4,5)$ trisphosphate [PtdIns $(3,4,5) \mathrm{P} 3]$, which binds to the pleckstrin-homology domain of target proteins, including Akt and phosphoinositide-dependent kinase 1 (PDK1). Activation of Akt is of particular importance since it has multiple downstream targets which control glucose homeostasis, cell survival, and gene transcription [41]. Akt is also involved in regulating the effects of insulin and insulinlike growth factor-1 (IGF1) on mTORC1 activation by inhibiting the tumor suppressor complex, TSC1-TSC2, that releases the small GTPase, Rheb (ㅅA in brain). GTP-bound Rheb further enables mTORC1 signaling to its downstream targets, S6K1 and 4EBP1 [36]. (mTORC1 will be referred to as mTOR for the remainder of this perspective).

Rapamycin (sirolimus) is a macrolide immunosuppressor with similarities to the calcineurin inhibitor (CNI) tacrolimus in its molecular structure. Rapamycin binds to the intracellular receptor, the immunophilin FKBP-12 (FK-506 binding protein of $12 \mathrm{kd}$ ), that forms a complex with the FRB (FKBP-12/rapamycin binding) domain of mTOR. This conserved domain resides outside the catalytic domain and is unique to mTOR, and explains the high specificity of rapamycin-like drugs for its target and the ability of rapamycin to identify pathways regulated by mTOR $[35,42]$. In most cases rapamycin sensitivity is considered to be a very specific indicator of mTOR-mediated signaling [35].

\section{REGULATION OF mTOR IN $\beta$-CELLS BY NUTRIENTS AND GROWTH FACTORS}

The pancreatic $\beta$-cell is unique in its ability to metabolically regulate insulin secretion and also express components of the insulin and growth factor signaling cascade. Dann et al. [36] have shown that the kinase activity of mTOR cannot be triggered by PI-3K in the absence of nutrients and cellular energy. In $\mathrm{CHO}$ cells, the metabolism of glucose was required for insulin to mediate the phosphorylation of eukaryotic initiation factor, eIF-4E [43]. Our initial studies in rat islets established that glucose metabolism and insulin signaling, in an amino acid dependent manner, resulted in phosphorylated 4EBP1 and S6K1 $[44,45]$. The phosphorylation of 4EBP1 and S6K1 was prevented by rapamycin. Rapamycin also inhibited glucosestimulated ${ }^{35} \mathrm{~S}$-methionine incorporation into islet protein [44]. Overall these studies demonstrated that the production of energy derived from glucose metabolism and insulin signaling, in an amino acid dependent manner, regulates protein synthesis through mTOR activation.

These findings also highlighted an essential requirement for branched chain amino acids to facilitate metabolic and insulin signaling through mTOR. In RINm5F cells, leucine in combination with glutamine, stimulated S6K1 phosphorylation via the mTOR pathway [45]. Leucine has been shown to be unique in its ability to activate translation initiation independent of insulin and insulin-like growth factors (IGFs) [46-49]. Our data support the conclusion that in $\beta$-cells, leucine and glutamine serve as mitochondrial fuels through the production of acetyl-CoA and glutamine as an allosteric activator of glutamate dehydrogenase forming $\alpha$ ketoglutarate from glutamate that enters the KREB's cycle. Thus, the metabolism of glucose and amino acids, designated as nutrient signaling, energizes the mitochondria and provides metabolically generated secondary signals, including ATP, cAMP, and $\mathrm{Ca}^{2+}$, necessary for mTOR activation $[33,45,49,50]$.

RINm5F cells require only amino acid stimulation to fully activate mTOR. In contrast, primary rodent and human islets also require elevated glucose concentrations for the production of metabolically generated secondary signals for mTOR activation [33]. Importantly, human islets exhibited a variable response to elevated glucose, not always activating the downstream targets of mTOR, S6K1 and 4EBP1 (unpublished data). This indicated that a metabolic dysfunction preventing mTOR activation might be responsible for this variable response to glucose in human islets.

In additional experiments involving leucine and insulin infusion in human subjects, insulin increased Akt phosphorylation, but leucine was ineffective in biopsies obtained from skeletal muscle in vivo. However, leucine and insulin were each effective alone and also synergized to phosphorylate S6K1 [51]. This indicates that leucine, in combination with insulin, produces a synergistic effect on mTOR through nutrient and insulin signaling pathways. In addition, leucine, through nutrient signaling independent of insulin, activates mTOR and may have a role in skeletal muscle protein synthesis [51].

Our next studies focused on determining the metabolic secondary signals linking cellular metabolism to mTOR regulation. In $\beta$-cells, the metabolism of elevated concentrations of glucose and amino acids increases the ATP/ADP ratio that inhibits $\mathrm{K}_{\mathrm{ATP}}$ channels, resulting in membrane depolarization and an influx of extracellular $\mathrm{Ca}^{2+}$. We found that exposure of rat islets to an agent that increases extracellular $\mathrm{Ca}^{2+}$ influx, glyburide, also increased S6K1 phosphorylation. In addition, forskolin and Exenatide, which increase cAMP levels and mobilize intracellular $\mathrm{Ca}^{2+}$, also increased S6K1 phosphorylation [52]. Conversely, 
diazoxide, nifedipine and BAPTA that reduce intracellular $\mathrm{Ca}^{2+}$ levels, decreased S6K1 phosphorylation. All of these effects on S6K1 phosphorylation were blocked by rapamycin, indicating a role for mTOR. Other investigators demonstrated that the $\alpha 1 \mathrm{D}$ subunit of the L-type calcium channel is required for proper $\beta$-cell development in the postnatal pancreas. In the $\alpha 1 \mathrm{D}$ knockout mouse, $\beta$-cell proliferation was decreased, suggesting that a defect in $\mathrm{Ca}^{2+}$ influx may be partly responsible for a reduction in $\beta$-cell mass [53]. In addition, other studies indicated that S6K1 requires a $\mathrm{Ca}^{2+}$ dependent priming event for activation $[54,55]$.

\section{DNA SYNTHESIS AND CELL CYCLE PROGRESSION IN RAT ISLETS}

Based on our findings suggesting a role for metabolic signals in regulating the mTOR pathway, we extended our studies to DNA synthesis and cell cycle progression. As shown in Fig. (2A), a 4-day exposure of rodent islets to elevated glucose compared to basal glucose increased ${ }^{3} \mathrm{H}$ thymidine incorporation (1.5-2-fold), as an indicator of DNA synthesis. Rapamycin dose-dependently inhibited this glucose-induced increase as well as basal levels of DNA synthesis. Treatment of rodent islets with glyburide at basal glucose also increased DNA synthesis that was blocked by rapamycin (Fig. 2B). To ascertain if glyburide-mediated DNA synthesis is due to cytosolic $\mathrm{Ca}^{2+}$ derived from extracellular media, we used nifedipine $(10 \mu \mathrm{M})$, an inhibitor of the L-type $\mathrm{Ca}^{2+}$ channel. We observed that nifedipine blocked glyburide-stimulated DNA synthesis (Fig. 2B, lane 5) to a level comparable to basal glucose (lane 1). These results supported the conclusion that the ability of glyburide

A.

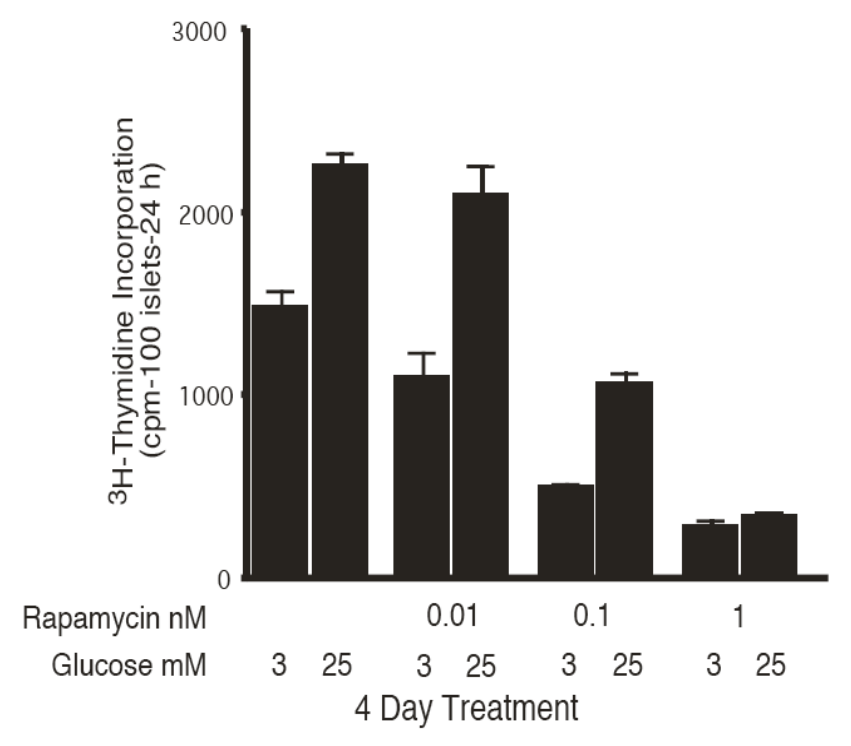

to mediate ${ }^{3} \mathrm{H}$-thymidine incorporation is due, in part, to an increase in $\mathrm{Ca}^{2+}$ influx through the nifedipine-sensitive Ltype $\mathrm{Ca}^{2+}$ channel and the mTOR pathway [56].

Our next approach was to determine whether diazoxide, an opener of $\mathrm{K}_{\text {ATP }}$ channels, would decrease glucosestimulated DNA synthesis due to its ability to attenuate $\mathrm{Ca}^{2+}$ influx. As shown in Fig. (3), diazoxide paradoxically enhanced the ability of elevated glucose to stimulate DNA synthesis (lane 3 versus lane 2). Interestingly, nifedipine failed to mimic the potentiating effect of diazoxide on glucose-stimulated DNA synthesis [56]. These unexpected results suggested that diazoxide might exert multiple effects to mediate the potentiation of glucose-stimulated DNA synthesis in addition to the opening of plasma membrane $\mathrm{K}_{\text {ATP }}$ channels [56]. Nifedipine $(10 \mu \mathrm{M})$ also failed to inhibit glucose-induced S6K1 phosphorylation in rat islets, although nifedipine in combination with BAPTA, which also lowered intracellular $\mathrm{Ca}^{2+}$ levels, reduced S6K1 phosphorylation [52]. Cell cycle analysis of rodent islets treated with glucose or glyburide indicated a reduction of cells in $\mathrm{G}_{0} / \mathrm{G}_{1}$ phase and a concomitant accumulation in S phase (Fig. 4). Rapamycin $(25$ and $100 \mathrm{nM}$ ) blocked this progression by $32 \%$ and $61 \%$, respectively [56]. Diazoxide failed to increase $\mathrm{S}$ phase accumulation even though it significantly increased ${ }^{3} \mathrm{H}-$ thymidine incorporation as discussed above (data not shown). Based on these results in rat islets, we concluded that elevated glucose $(20 \mathrm{mM})$ or glyburide $(10 \mathrm{nM})$ increases DNA synthesis and cell cycle progression in rodent islets, however, the effect of elevated glucose on DNA synthesis appears to be independent of extracellular $\mathrm{Ca}^{2+}$, whereas the effect of glyburide is dependent on extracellular $\mathrm{Ca}^{2+}$.

B.

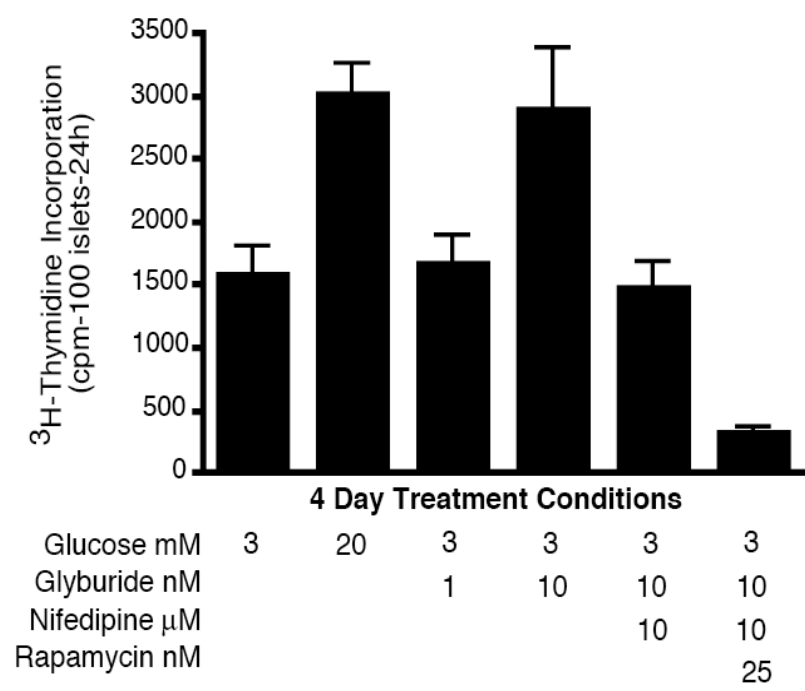

Fig. (2). (A) Glucose enhances DNA synthesis in a rapamycin-sensitive manner. Rat islets (100) were cultured for 4 days in CMRL-1066 culture media (CMRL) as indicated. ${ }^{3} \mathrm{H}$-thymidine incorporation was determined during the final $24 \mathrm{~h}$. Data are representative of two experiments with triplicate samples. Reprinted with permission from ref. [52]. (B) Stimulatory effect of glyburide on DNA synthesis at basal glucose is modulated by $\mathrm{Ca}^{2+}$ influx. Rat islets (100) were cultured for 4 days in CMRL as indicated and ${ }^{3} \mathrm{H}$-thymidine incorporation determined during the final 24 h. Data are the means \pm S.E. of $n=3$ experiments with triplicate samples. Reprinted with permission from ref. $[56]$. 


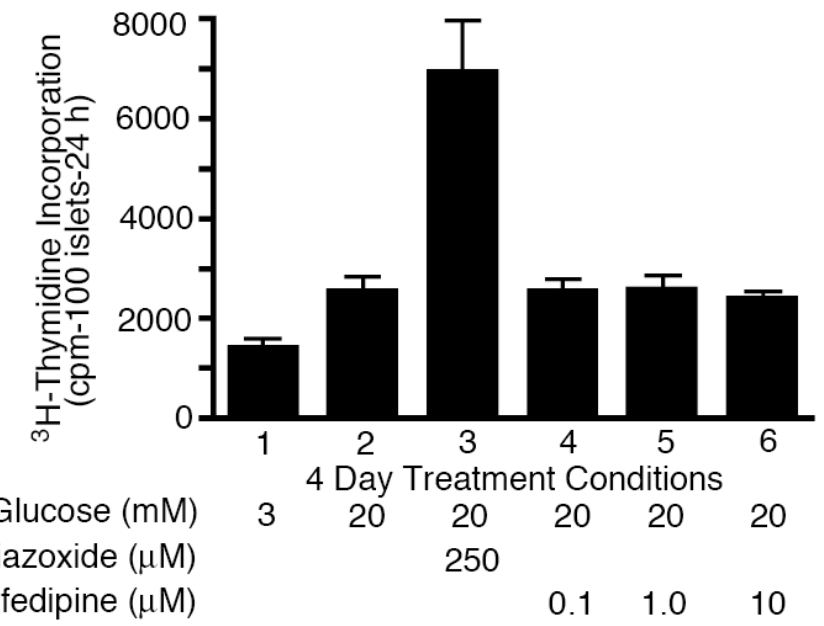

Fig. (3). Diazoxide increases glucose stimulated DNA synthesis independent of its role in opening $\mathrm{K}_{(\mathrm{ATP})}$ channels. Rat islets (100) were cultured for 4 days in CMRL as indicated and ${ }^{3} \mathrm{H}$-thymidine incorporation determined during the final $24 \mathrm{~h}$. Data are the means \pm S.E. of $n=3$ experiments with triplicate samples. Reprinted with permission from ref. [56].
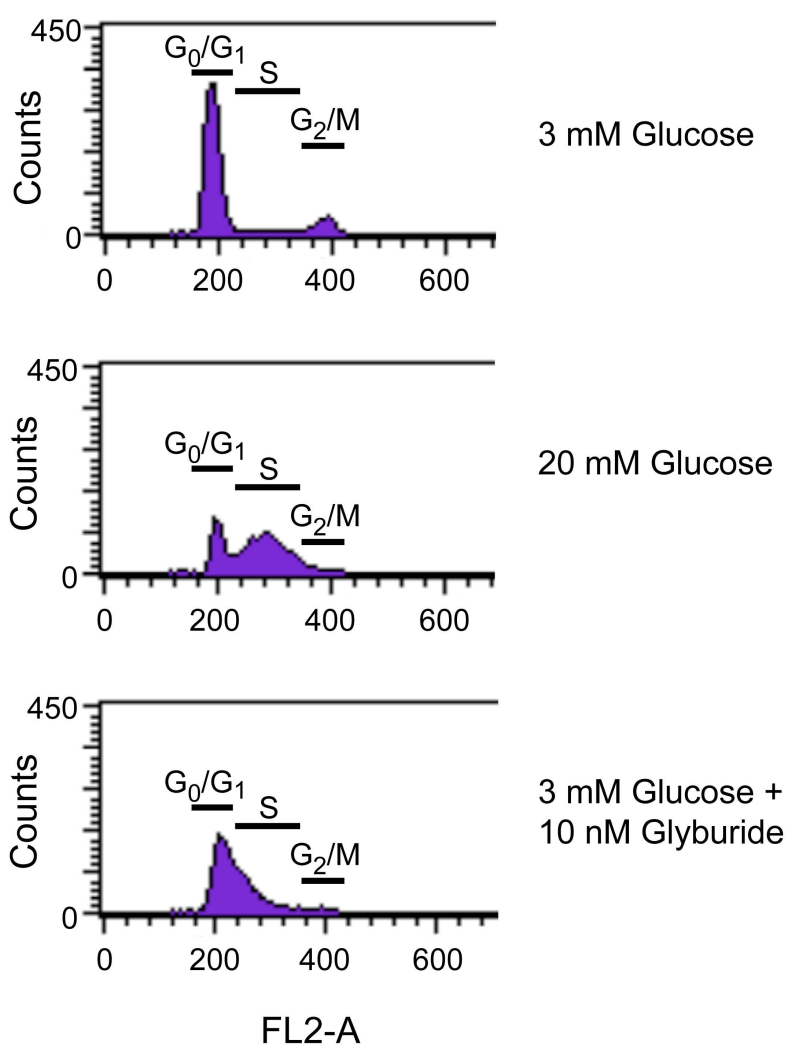

Fig. (4). Cell cycle analysis of glucose- and glyburide- stimulated rat islets. Islets (200) were cultured for 4 days in CMRL as indicated. The medium was changed after 2 days. At the end of the 4 day period, islets were dispersed into single cells, stained with propidium iodide and processed for flow cytometry to determine cell cycle progression. Data represents the \% of gated cells in each cell cycle phase. Data are representative of $n=3$ experiments. Reprinted with permission from ref. [56]

\section{REGULATION OF mTOR, DNA SYNTHESIS, AND CELL CYCLE PROGRESSION IN HUMAN ISLETS}

Our next area of interest was to determine if nutrients (glucose and amino acids) and pharmacologic agents (glyburide and diazoxide) that were effective in enhancing mTOR-mediated DNA synthesis or cell cycle progression in rodent islets provided an effective strategy to enhance the survival, growth, and proliferative capacity of adult human islets. As previously discussed, in contrast to rat islets, human islets exhibited a variable response to these stimuli based on mTOR/S6K1 phosphorylation and also rarely increased DNA synthesis or entered the cell cycle. Since we had established that metabolic signaling by nutrients was important for the regulation of regenerative processes in rodent islets, we hypothesized that human islets may display a metabolic defect that prevented appropriate mTOR signaling. Thus, we began to experiment with another nutrient, palmitate and its ketone metabolite, acetoacetate. Although palmitate increased DNA synthesis, in a rapamycin sensitive manner, in rat islets (Fig. 5A), neither palmitate (Fig. 5B) nor elevated glucose (Fig. 5C) had an effect in human islets. Unexpectedly, the lithium component in the commercially available acetoacetate salt significantly enhanced DNA synthesis at basal and elevated glucose (Fig. 5C) in human islets in a rapamycin sensitive manner [57], whereas the sodium acetoacetate salt was ineffective (data not shown). These effects of lithium were consistent with earlier findings by Sjoholm et al. [58] demonstrating that lithium triggered DNA synthesis in fetal rat islets, although the mechanism responsible for this effect was not identified. A well-known action of lithium is the phosphorylation of glycogen synthase kinase (GSK-3) that results in GSK-3 inhibition. We speculated that the mechanism whereby lithium exerts these positive effects on DNA synthesis might be through activation of the Wnt signaling pathway by direct GSK-3 inhibition and also involved the mTOR pathway, based on rapamycin sensitivity.

\section{Wnt/GSK-3/ $\beta$-CATENIN SIGNALING PATHWAY}

The Wnt signaling pathway regulates a wide range of cellular functions including cell growth, proliferation, polarity, differentiation and development [59,60]. Fig. (1) depicts schematically pathways involved in Wnt signaling. Wnt signaling is activated by the binding of Wnt ligands to membrane-spanning receptors designated as Frizzleds (Fz) and the transmembrane protein LRP. GSK-3 is a highly conserved serine/threonine kinase that regulates a number of diverse signaling pathways. Different than most protein kinases, GSK-3 is active in the non-phosphorylated form under basal glucose conditions and is primarily regulated by inactivation due to phosphorylation. One primary target of GSK-3 is the transcription co-factor, $\beta$-catenin. In the absence of Wnt signaling, active GSK-3 forms a complex with other proteins including the adenomatous polyposis coli protein (APC), casein kinase $1 / 2(\mathrm{CK} 1 / 2)$, Axin, protein phosphatase 2A (PP2A) and $\beta$-catenin. This complex facilitates GSK-3-mediated phosphorylation of cytoplasmic $\beta$-catenin that targets its degradation by ubiquitination. In the presence of a Wnt ligand, the disheveled (Dsh)/FRAT complex inhibits the activity of the GSK-3 complex, releasing $\beta$-catenin which translocates to the nucleus. Lithium and 1-Akp can also inactivate the GSK-3 complex, 

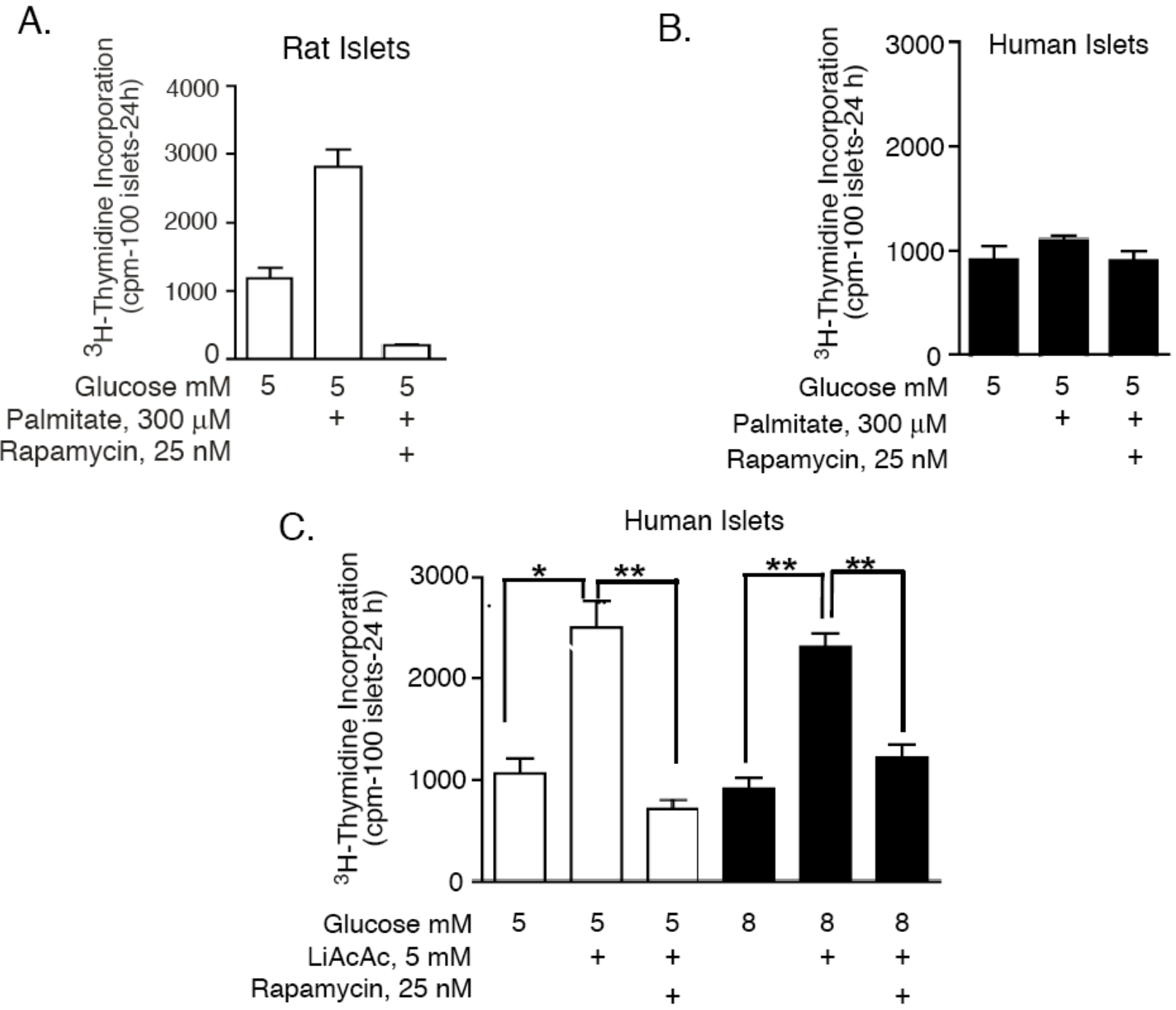

Fig. (5). Effects of palmitate and lithium acetoacetate on DNA synthesis in rat and human islets. Rat (A) or human (B and C) islets were cultured for 4 days in CMRL as indicated and ${ }^{3} \mathrm{H}$-thymidine incorporation was determined during the final $24 \mathrm{~h}$. Palmitate was complexed to fatty acid-free BSA at a 4:1 ratio estimated to yield unbound fatty acid concentrations in the nanomolar range. Data are the means \pm S.E. of $n$ $=3$ experiments with triplicate samples. (Data are the means \pm S.E. of $\mathrm{n}=3$ experiments with triplicate samples. ${ }^{*} \mathrm{p}<0.05, * * \mathrm{p}<0.01$ denote significant differences between bracketed conditions.

thus releasing cytoplasmic $\beta$-catenin from the complex and allowing $\beta$-catenin to translocate to the nucleus and interact with the TCF family of DNA binding factors necessary for the transcription of targeted genes $[60,61]$.

The Wnt signaling pathway is also activated by insulin and insulin-like growth factors-1/2 (IGF1/2). Under normal physiological conditions, insulin and IGF1/2 inhibit GSK-3 through Akt-mediated phosphorylation of GSK-3 at the Ser 21/9 residues [60-64]. Recent reports have also highlighted the importance of insulin signaling in stimulating the expression of a number of proto-oncogenes, including c-Myc and cyclin D1, which are suggested to be downstream targets of Wnt signaling $[65,66]$.

Lithium, an agent used as a mood stabilizer for decades, was first connected to GSK-3 inhibition due to its ability to mimic Wnt signaling in Xenopus development $[67,68]$. Although lithium has multiple effects, Klein and Melton [67] determined that by directly and potently inhibiting GSK-3 $\beta$, lithium regulates Xenopus embryo development. They further established that inhibition of another target of lithium, inositol monophosphatase, was not responsible for the effects of lithium on embryo morphogenesis. Since lithium mimics the function of Wnt activation, it has been broadly utilized in studying the functional outcome of Wnt activation and target gene expression $[68,69]$. Lithium at therapeutic concentrations in patients $(1-5 \mathrm{mM})$ inhibits by phosphorylation the activity of GSK-3 in both cell-free and intact cells, thus mimicking the effects of insulin and growth factors. The inactivation of GSK-3 by lithium leads to the accumulation of free cytoplasmic $\beta$-catenin and its translocation to the nucleus.

\section{REGULATION OF THE Wnt/GSK-3/ $\beta$-CATENIN PATHWAY IN HUMAN ISLETS}

In our studies using adult human islets, $\mathrm{LiCl}$ ( 5 or 10 $\mathrm{mM}$ ) in combination with $8 \mathrm{mM}$ glucose significantly enhanced DNA synthesis in human islets above that of $8 \mathrm{mM}$ glucose alone in a rapamycin sensitive manner (Fig. 6A) [57]. As shown in Fig. (6B), 1-azakenpaullone (1-Akp), a 
highly potent and specific GSK-3 inhibitor [70], also significantly enhanced DNA synthesis in human islets above that of $8 \mathrm{mM}$ glucose alone in a dose dependent manner [57]. This increase in DNA synthesis was significantly blocked by rapamycin indicating a role for the mTOR pathway. Exposure of human islets to $8 \mathrm{mM}$ glucose plus $15 \mu \mathrm{M} 1$ Akp significantly decreased cells in $\mathrm{G}_{0} / \mathrm{G}_{1}$ and increased cells in $S$ phase with no change in $\mathrm{G}_{2} / \mathrm{M}$, whereas an increase in glucose from 5 to $8 \mathrm{mM}$ alone failed to exert any significant effects on $G_{0} / G_{1}, S$, or $G_{2} / M$ phases in human islets (Fig. 6C). All of these changes were blocked by rapamycin [57]. These positive effects of GSK-3 inhibition on DNA synthesis and cell cycle progression in human islets were highly reproducible. Taken together, our studies indicated that in human islets, the regulation of both the GSK-3/ $\beta$-catenin and mTOR signaling pathways were required to recapitulate the positive effects on DNA

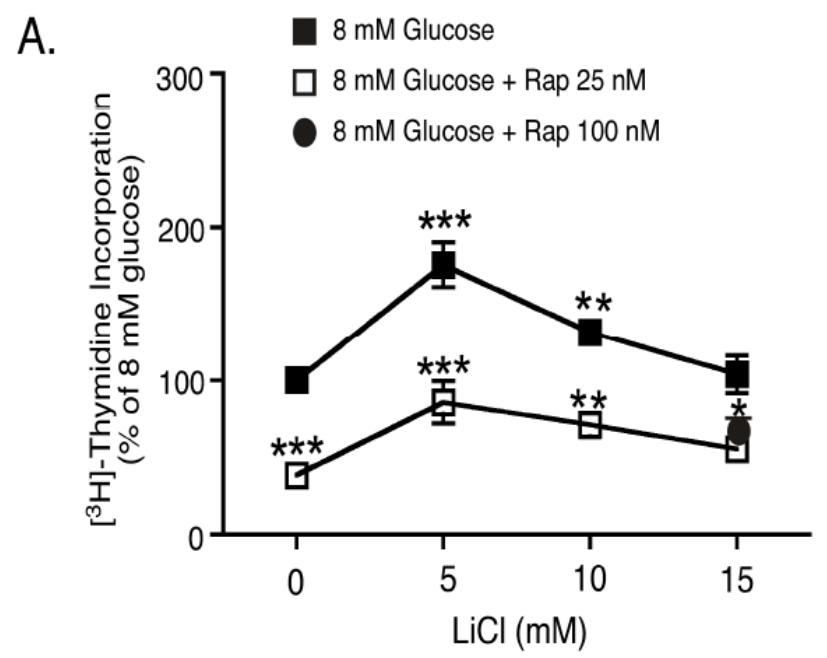

synthesis and cell cycle progression observed previously in rodent islets. It is important to note that these positive effects of GSK-3 inhibition on DNA synthesis and cell cycle progression and the inhibition by rapamycin were analyzed using intact human and rodent islets and not purified $\alpha$ - and $\beta$-cells. Rodent islets contain predominantly $\beta$-cells but human islets may contain more than $50 \%$ non $\beta$-cells. The data presented in Fig. (8) (to be discussed subsequently) demonstrates proliferation in human $\beta$-cells $\left(\mathrm{Ki}-67^{+} /\right.$insulin $^{+}$ co-stained cells). Additional studies will be conducted in order to further establish a direct connection of GSK-3 inhibition to proliferation in specific islet cell types.

Other studies have also focused on the role of GSK-3 inhibition in regulating regenerative processes in cell lines and rodent islets. Liu et al. [71] reported that mice with $\beta$ cell overexpression of activated GSK-3 resulted in low $\beta$-cell mass and proliferation. Recently, Mussmann et al. [72]
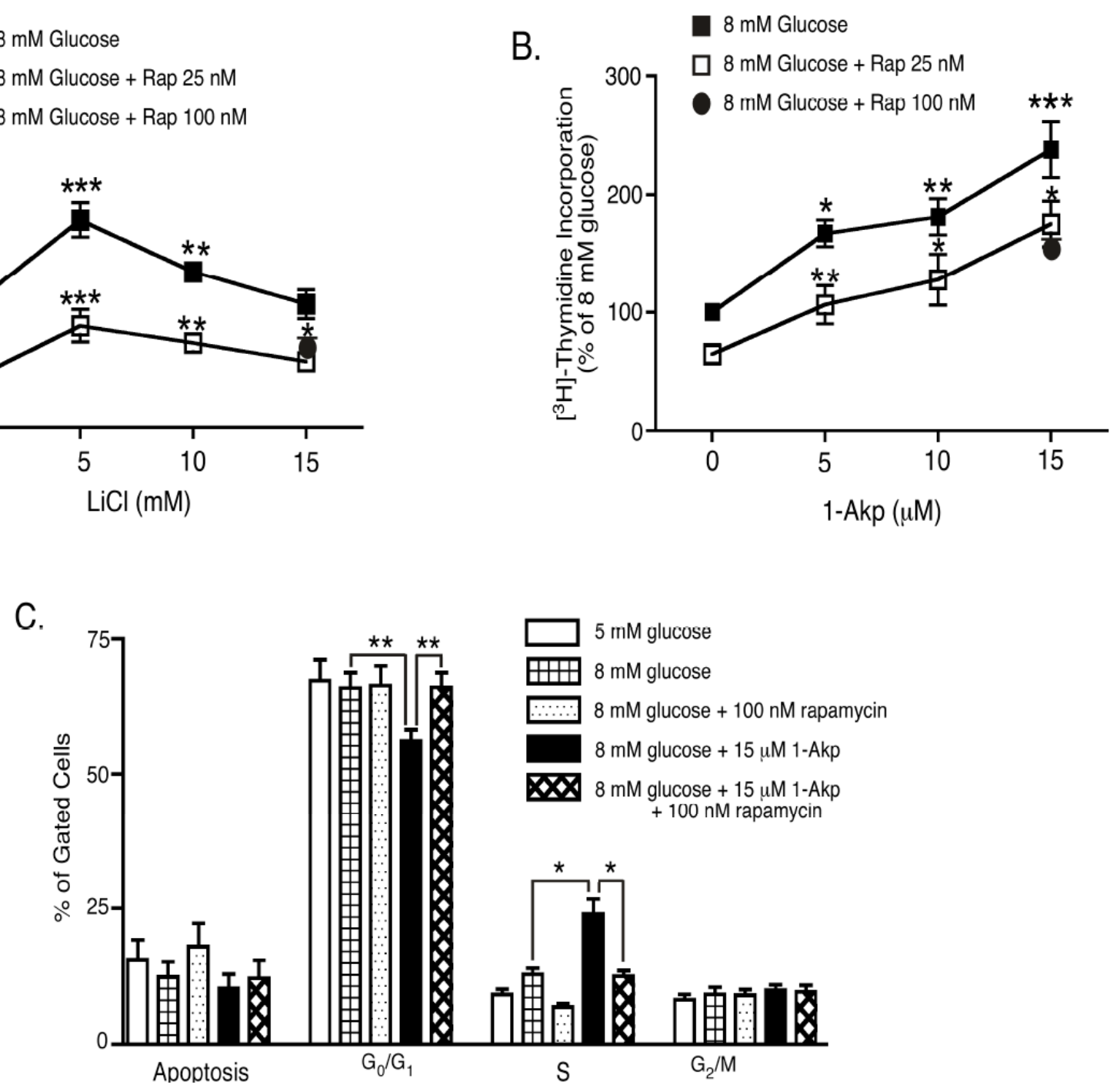

Fig. (6). Effect of GSK-3 inhibition on mTOR-dependent regenerative processes in human islets. Effect of $\mathrm{LiCl}(\mathbf{A})$ and 1-Akp (B) on mTOR-dependent DNA synthesis. Islets (100) were cultured for 4 days in CMRL as indicated and ${ }^{3} \mathrm{H}$-thymidine incorporation determined during the final $24 \mathrm{~h}$. Data are the means \pm S.E. of $\mathrm{n}=2-5$ experiments; ${ }^{*} \mathrm{p}<0.05,{ }^{* *} \mathrm{p}<0.01$, and ${ }^{* * *} \mathrm{p}<0.001$ indicate significant differences from $8 \mathrm{mM}$ glucose alone. (C) Islets (200) were cultured in CMRL as indicated. At the end of the 4-day incubation period, islets were dispersed into single cells, stained with propidium iodide and processed for flow cytometry to determine cell cycle progression. Data are the means \pm S.E. of $\mathrm{n}=3$ experiments. ${ }^{* *} \mathrm{p}<0.01$ and $* * * \mathrm{p}<0.001$ denote significant differences between the bracketed conditions. Reprinted with permission from ref. [57]. 


\section{Human Islets}

A.

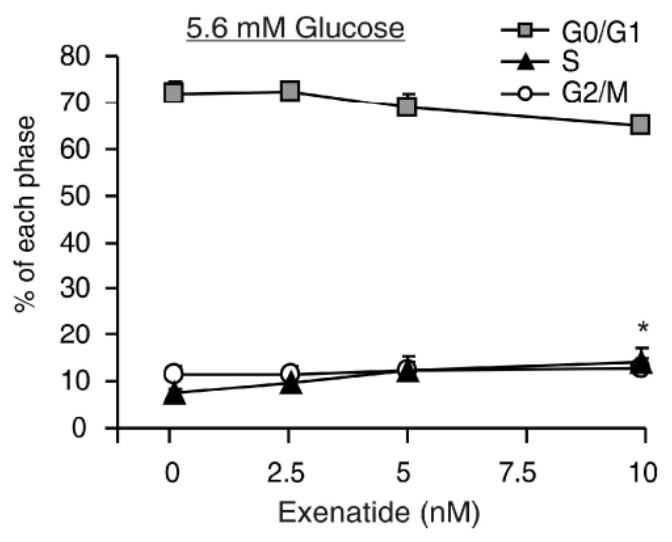

B.

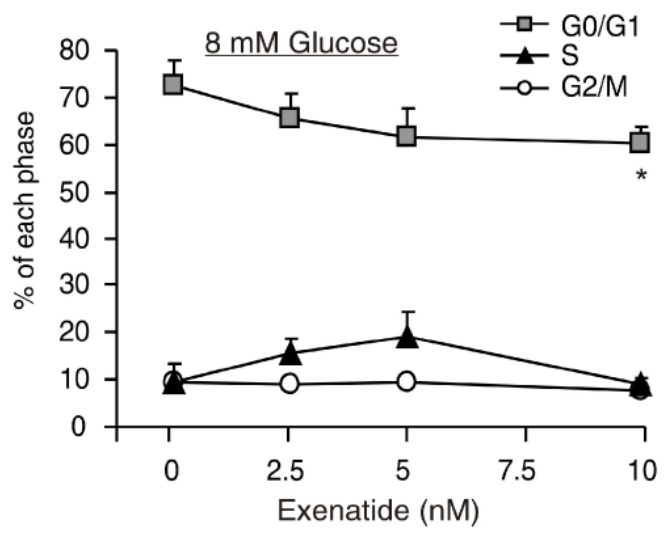

C.

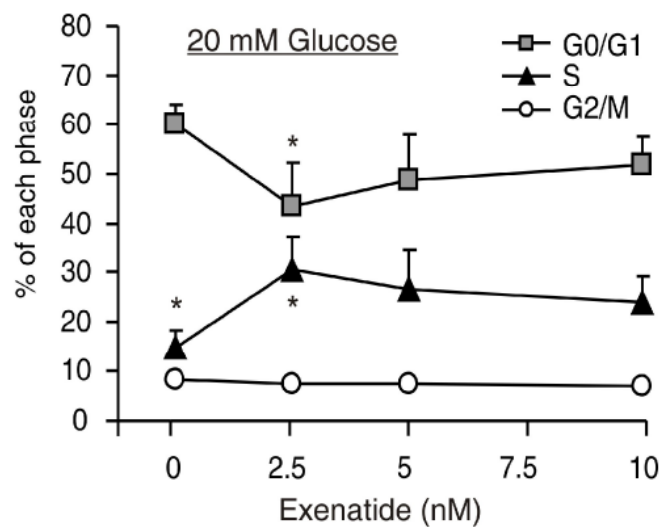

D.

\section{Rat Islets}

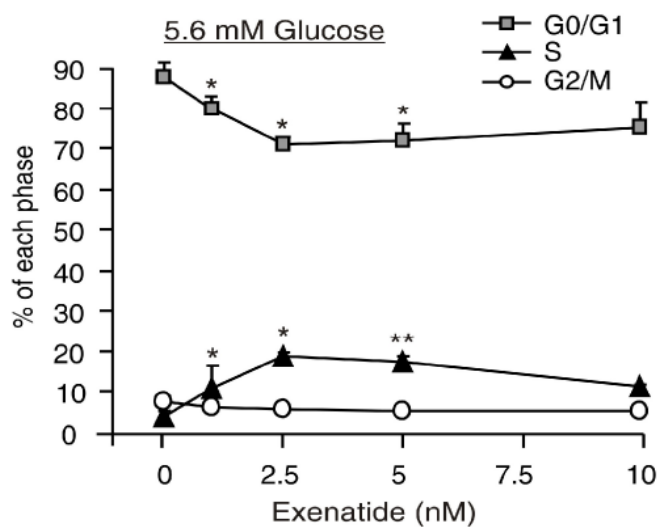

E.

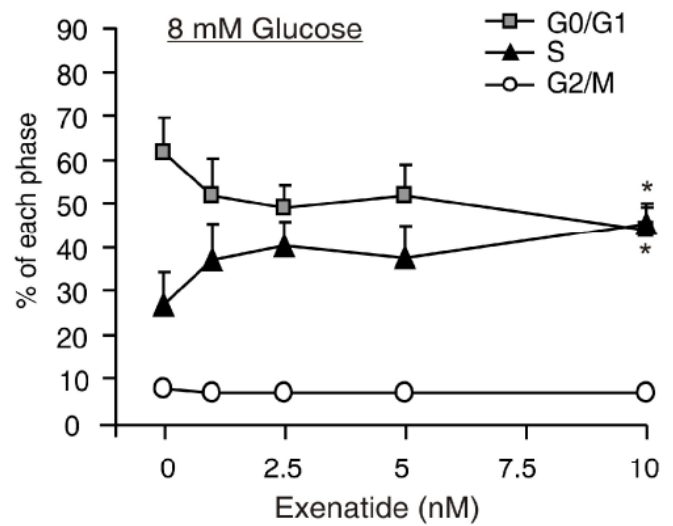

F.

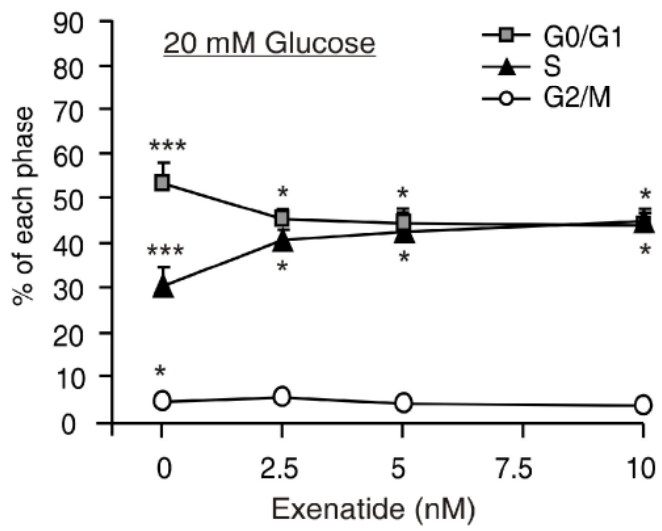

Fig. (7). Dose dependent effects of Exenatide on cell cycle progression in human (A-C) and rat (D-F) islets. Islets (200) were incubated in CMRL as indicated for 4 days. Media was changed daily. At the end of the 4 day period, islets were dispersed into single cells, stained with propidium iodide and processed for flow cytometry to determine cell cycle progression. Data are the means \pm S.E. of $n=3-4$ experiments with duplicate samples in each experiment. ${ }^{*} \mathrm{p}<0.05,{ }^{*} \mathrm{p}<0.01$ and $* * * \mathrm{p}<0.001$ denote significant differences. See text for statistical comparisons.

reported that treatment of isolated rat islets with structurally diverse small molecule inhibitors of GSK-3 increased the rate of $\beta$-cell replication by 2-3 fold relative to controls.

\section{EFFECTS OF EXENATIDE ON THE MTOR AND Wnt/GSK-3/ $\beta$-CATENIN PATHWAYS IN HUMAN AND RAT ISLETS}

The insulinotropic hormone GLP-1 (glucagon-like peptide-1) and its long acting agonist, exendin-4 (Exd4,
Exenatide), exert positive effects on $\beta$-cell function including glucose-dependent insulin secretion as well as proinsulin biosynthesis. Multiple anti-diabetogenic actions of GLP-1 have since been discovered, including the stimulation of proliferation and inhibition of apoptosis in pancreatic $\beta$ cells [73-75]. Liu and Habener [15] proposed that activation of the GLP-1 receptor (GLP-1R) by GLP-1 or Exd4 leads to the accumulation of cAMP and activation of cAMPdependent protein kinase A (PKA), mitogen-activated 


\section{Human Islets}

A.

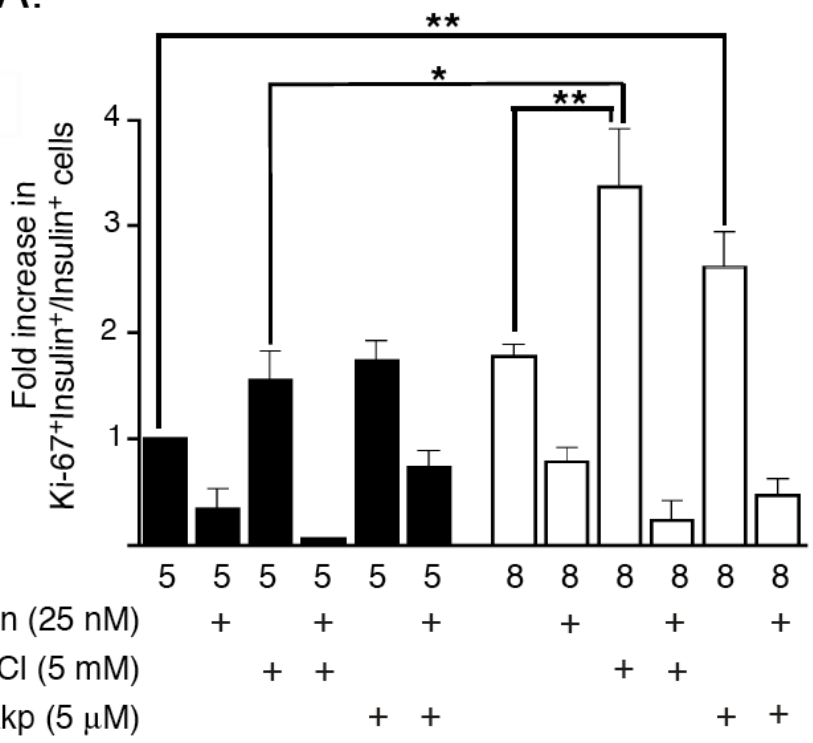

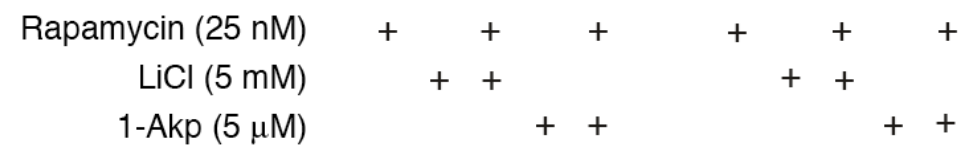

B.

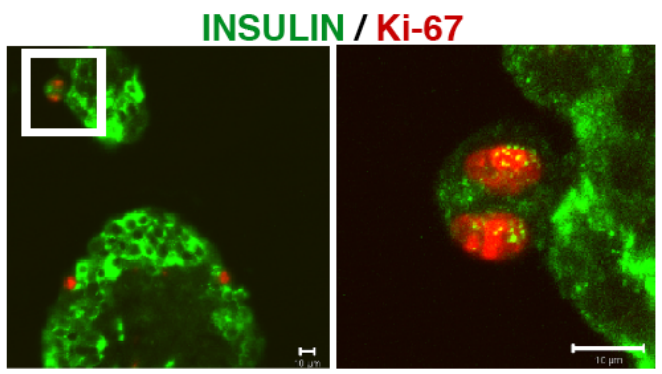

Fig. (8). Lithium and 1-Akp in combination with glucose stimulates $\beta$-cell proliferation in human islets. (A) Fold increase (with respect to 5 $\mathrm{mM}$ glucose) in the ratio of proliferating $\beta$-cells to total number of insulin ${ }^{+} \beta$-cells as determined by immunohistochemical analysis. Data presented are the mean $\pm \mathrm{SE}$ of three independent experiments. For each group per experiment, $\sim 5,000-6,000 \beta$-cells were counted. Glucose $(8 \mathrm{mM})+\mathrm{LiCl}$ significantly increased the number of $\mathrm{Ki}-67^{+} /$insulin ${ }^{+}$cells compared to that of $8 \mathrm{mM}$ glucose alone or $5 \mathrm{mM}$ glucose $+\mathrm{LiCl}$. A 4 -fold increase in proliferating $\beta$-cells was noted in human islets treated with $8 \mathrm{mM}$ glucose $+\mathrm{LiCl}(0.71 \%+0.3)$ in contrast to $5 \mathrm{mM}$ glucose $+\mathrm{LiCl}(0.168 \%+0.08)$ or $8 \mathrm{mM}$ glucose alone $(0.34 \% \pm 0.2)$. Rapamycin treatment resulted in significantly fewer $\mathrm{Ki}-67^{+} /$insulin $^{+}$ cells in all treatment conditions. $* \mathrm{P}<0.05, * * \mathrm{P}<0.01$, and $* * * \mathrm{P}<0.001$ denote significant differences between the bracketed conditions. (B) Representative confocal image of paraffin-embedded intact human islets treated for 4 days as indicated. Image on the far right is a fivefold magnification of the white inset box on the upper left, to display confirmed colocalization of Ki-67 (red nuclei) and insulin (green cytoplasm) in two adjacent $\beta$-cells or a dividing $\beta$-cell. Reprinted with permission from ref. [57].

protein kinase (MEK), and Akt. PKA directly phosphorylates $\beta$-catenin on Ser675 to stabilize $\beta$-catenin and enhance TCF7-L2 activation of gene expression in $\beta$ cells [15]. Akt and MEK/ERK signaling also contribute to $\beta$ catenin stabilization. In addition, these investigators found by microarrays that GLP-1 and Exd4 also induce the expression of genes in both the Wnt signaling pathway and their target genes [15].

Similar to these findings, we observed positive effects of Exenatide on regenerative processes in human islets. Treatment of human islets with 5.6 or $20 \mathrm{mM}$ glucose and $2.5 \mathrm{nM}$ Exenatide for 4 days, modestly increased DNA synthesis, although not significantly. DNA synthesis in response to $20 \mathrm{mM}$ glucose $\pm 2.5 \mathrm{nM}$ Exenatide was significantly inhibited by rapamycin (data not shown). Exenatide treatment of human islets also stimulated cell cycle progression. Fig. (7A) shows that $10 \mathrm{nM}$ Exenatide at $5.6 \mathrm{mM}$ glucose significantly increased the percentage of cells in $\mathrm{S}$ phase from 7 to $14 \%(\mathrm{p}<0.05)$ compared to 5.6 $\mathrm{mM}$ glucose. Similarly in Fig. (7B), $10 \mathrm{nM}$ Exenatide and 8 $\mathrm{mM}$ glucose significantly reduced the percentage of cells in $\mathrm{G}_{0} / \mathrm{G}_{1}$ phase from 75 to $61 \%(\mathrm{p}<0.05)$ compared to $8 \mathrm{mM}$ glucose. In the presence of $20 \mathrm{mM}$ glucose, $2.5 \mathrm{nM}$ Exenatide caused a significant decrease of cells in $\mathrm{G}_{0} / \mathrm{G}_{1}$ phase (64 to $47 \%, \mathrm{p}<0.05)$ and a concomitant increase in cells in $\mathrm{S}$ phase $(18$ to $34 \%, \mathrm{p}<0.05)$ (Fig. 7C). Increasing glucose from 5.6 to $8 \mathrm{mM}$ in the absence of Exenatide had no effect on cell cycle progression in human islets (Fig. 7A, B). Increasing glucose from 5.6 to $20 \mathrm{mM}$ glucose resulted in a small but significant increase in the percentage of cells in $\mathrm{S}$ phase ( 7 to $18 \%, \mathrm{p}<0.05)$. Overall, these data demonstrate that Exenatide in a glucose-dependent manner significantly increased cell cycle progression in human islets. Thus, the most significant effects were observed at elevated glucose concentrations.

In rat islets (Fig. 7D, F) increasing glucose from 5.6 to $20 \mathrm{mM}$ in the absence of Exenatide, resulted in statistically significant changes in cell cycle progression in $\mathrm{G}_{0} / \mathrm{G}_{1}, \mathrm{~S}$ and $\mathrm{G}_{2} / \mathrm{M}$ phases compared to each phase at $5.6 \mathrm{mM}$ glucose. In Fig. (7D), Exenatide (1, 2.5 and $5 \mathrm{nM})$ caused a significant decrease of cells in $\mathrm{G}_{0} / \mathrm{G}_{1}$ phase $(\mathrm{p}<0.05)$ and a concomitant increase in cells in $S$ phase $(p<0.05$ or $p<0.01)$. At elevated glucose ( 8 or $20 \mathrm{mM})$, Exenatide further significantly shifted cells from $G_{0} / G_{1}$ to $S$ phase at all doses compared to glucose in the absence of Exenatide (Fig. 7E, F).

Thus, Exenatide overcomes the inability of human islets to respond physiologically to elevated glucose for DNA synthesis and cell cycle progression, whereas Exenatide potentiates these regenerative processes in rat islets. Based on our findings and those of Liu et al. [15], we speculate that in human islets Exenatide may exert effects on regenerative processes through cAMP/PKA-mediated stabilization of $\beta$ catenin as well as activation of the mTOR pathway based on activation of $\mathrm{S} 6 \mathrm{~K} 1$ and rapamycin sensitivity [52]. 
Importantly, in addition to GSK-3 inhibitors, Exenatide is the only other treatment in our experimental designs that exerted a positive effect on DNA synthesis and cell cycle progression in human islets. These experiments were conducted using intact islets, thus further studies will need to address whether these effects of Exenatide occur in $\alpha$ - and/or $\beta$-cells. In addition, these studies will be extended beyond DNA synthesis and cell cycle progression to include techniques to measure cell proliferation.

\section{HUMAN $\beta$-CELL PROLIFERATION RESULTING FROM mTOR AND Wnt/GSK-3/ $\boldsymbol{\beta}$-CATENIN CROSSTALK}

Various investigators have reported $\beta$-cell proliferation in rodents, however, there is limited information on human $\beta$ cell proliferation. Parnaud et al. [76] performed an analysis of various growth factors, EGF, gastrin, and GLP-1, and extracellular matrices, all of which are known to induce $\beta$ cell proliferation in rodents. Using FACS purified human $\beta$ cells or intact human islets, regardless of the culture conditions, they failed to observe any human $\beta$-cells which were Ki-67 positive (a marker of cell proliferation). In addition, Meier et al. [77,78] studied the extent and timing of expansion, as well as the source of newly formed $\beta$-cells in human autopsy samples from infancy to young adult. They reported that $\beta$-cell mass was increased several fold from birth to adulthood, due to an increase in islet size and $\beta$-cells per islet, but not islet number. The authors also reported a high degree of individual variability in these parameters. This study reported a high rate of $\beta$-cell replication and mass expansion that occurred in postnatal islets that decreased through adulthood. Butler et al. also reported that obesity results in adaptive increases in $\beta$-cell mass in rodents of $\sim 10$ fold and in humans of only $\sim 0.5$ fold $[79,80]$.

A significant focus of our studies was to determine if GSK-3 inhibition results in mTOR-mediated human $\beta$-cell proliferation in vitro. Fig. (8A) demonstrates that primary human $\beta$-cells require an increased glucose concentration ( 8 $\mathrm{mM}$ ) in combination with GSK-3 inhibition by $\mathrm{LiCl}$ or 1 Akp to attain significant increases in proliferation. The most significant increases in $\mathrm{Ki}-67 /$ insulin positive cells were observed in comparing $8 \mathrm{mM}$ glucose $+\mathrm{LiCl}$ with 5 or $8 \mathrm{mM}$ glucose alone or with $5 \mathrm{mM}$ glucose $+\mathrm{LiCl}$ (See Fig. 8 legend for fold and percent increase in $\mathrm{Ki}-67 /$ insulin positive cells). An additional significant increase in $\mathrm{Ki}-67 /$ insulin positive cells was observed in comparing $8 \mathrm{mM}$ glucose +15 $\mu \mathrm{M} 1-\mathrm{Akp}$ with $5 \mathrm{mM}$ glucose alone. It is also noted that increases in glucose from 5 to $8 \mathrm{mM}$ glucose in the absence of GSK-3 inhibition failed to exert any significant differences in $\beta$-cell proliferation. The number of cells positively immunolabeled for $\mathrm{Ki}-67 /$ insulin in all treatment conditions was significantly blocked by rapamycin. Confocal microscopy was utilized to verify that the Ki-67 positive cells (red nuclei) were colocalized with insulin positive human $\beta$-cells (green cytoplasm) (Fig. 8B). In this same study, a number of human $\beta$-cells with positive immuno-labeling for $\mathrm{Ki}-67$ or BrdU, exhibited a low level of insulin positive staining, indicating a low level of insulin granules. These human $\beta$ cells were not included in the quantitation of proliferation, thus our data might be an underestimation of total $\beta$-cell proliferation. This is consistent with other studies also showing that expansion of human islets resulted in lower $\beta$ cell insulin content [81]. We speculate that this may represent a temporary state in this subset of $\beta$-cells due to the large energy requirements for proliferation and insulin biosynthesis. We anticipate that once cell division has occurred and a basal condition attained, $\beta$-cell insulin biosynthesis will resume.

As discussed above (Fig. 8), there is a requirement for elevated glucose in combination with GSK-3 inhibition, to achieve significant increases in $\mathrm{Ki}-67$ or $\mathrm{BrdU}$ positive staining in human $\beta$-cells. In contrast, only basal glucose is required in combination with GSK-3 inhibition to activate the other regenerative processes including, DNA synthesis and cell cycle progression, in intact human islets. An explanation for this difference may be that the methodology used to quantify $\mathrm{Ki}-67$ and BrdU is specific for $\beta$-cells, whereas DNA synthesis and cell cycle progression data quantifies all islet cell types. In this study, we did not examine Ki-67 or BrdU positive staining in human islet $\alpha$ cells. Future studies will determine if GSK-3 inhibition in human islets results in similar effects in $\alpha$-cells compared to our $\beta$-cell findings.

Since we had established that both mTOR and GSK-3 pathways are involved in these regenerative processes in human islets, we attempted to determine the mechanisms responsible for crosstalk between these signaling pathways. We observed that GSK-3 inhibition by $\mathrm{LiCl}(10 \mathrm{mM})$ or 1Akp $(10 \mu \mathrm{M})$, in the presence of 5 or $8 \mathrm{mM}$ glucose, resulted in significant increases in $\beta$-catenin accumulation and translocation to the nucleus of human $\beta$-cells (Fig. 9A). Importantly, $\beta$-catenin translocation in response to GSK-3 inhibition was significantly rapamycin sensitive. This suggests that mTOR may exert an important role in this crosstalk mechanism by facilitating the nuclear translocation of $\beta$-catenin. Fig. (9B) demonstrates the criteria for determining $\beta$-catenin nuclear translocation in human $\beta$-cells with insulin positive (green) and $\beta$-catenin (red-cytoplasmic) or (purple-nuclear) staining (see Fig. 9B legend). Rulifson et al. [61] proposed that $\beta$-catenin signaling is both necessary and sufficient for $\beta$-cell proliferation in mouse islets, and that expression of activated $\beta$-catenin increases $\beta$-cell mass. However, these studies did not address the role of mTOR in combination with $\beta$-catenin signaling as a requirement for rodent $\beta$-cell proliferation. Interestingly, Rulifson et al. [61] indicated that the Wnt agonist, Wnt3a, failed to stimulate human $\beta$-cell proliferation. These observations with Wnt receptor agonists, suggest that direct inhibition of GSK-3 may be required for proliferation in human islets. Fig. 10 (see Fig. 10 legend) emphasizes schematically the involvement of mTOR crosstalk in the Wnt/GSK-3/ $\beta$-catenin signaling pathway to mediate $\beta$-catenin nuclear translocation.

Conversely, Inoki et al. [82] and Jin et al. [83] reported that inhibition of GSK-3 is required for mTOR activation and identified a key role for GSK-3, in a $\beta$-cateninindependent manner, to regulate mTOR signaling in non $\beta$ cells. Thus, we next examined whether GSK-3 inhibition has a positive effect on mTOR activation in human islets. However, GSK-3 inhibition exerted inconsistent and small effects on mTOR signaling in the presence of 5 or $8 \mathrm{mM}$ glucose [57]. In the absence of glucose, GSK-3 inhibitors resulted in a small increase in S6 phosphorylation (data not shown). We concluded that there is a minimal effect of 


\section{Human Islets}

A.

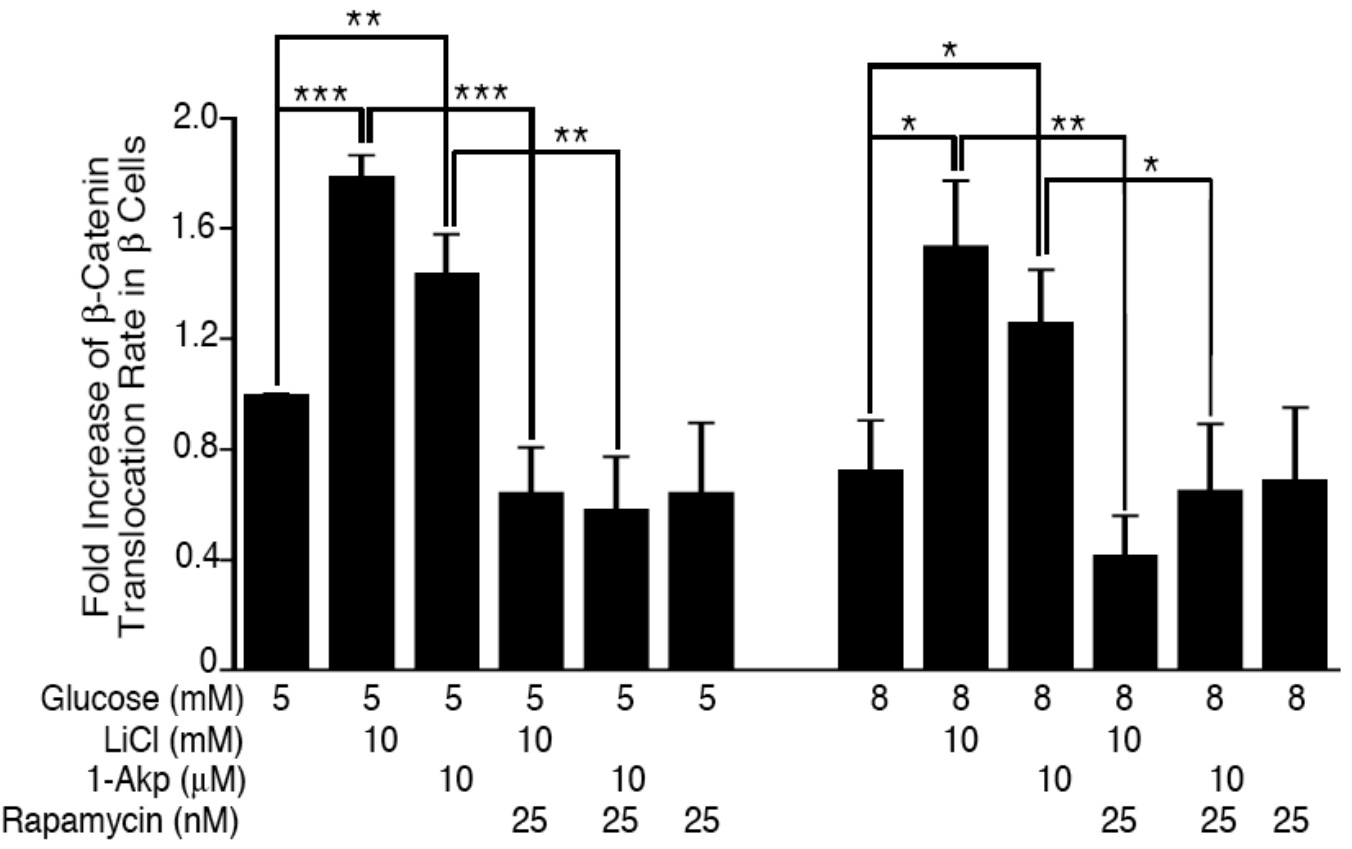

B.

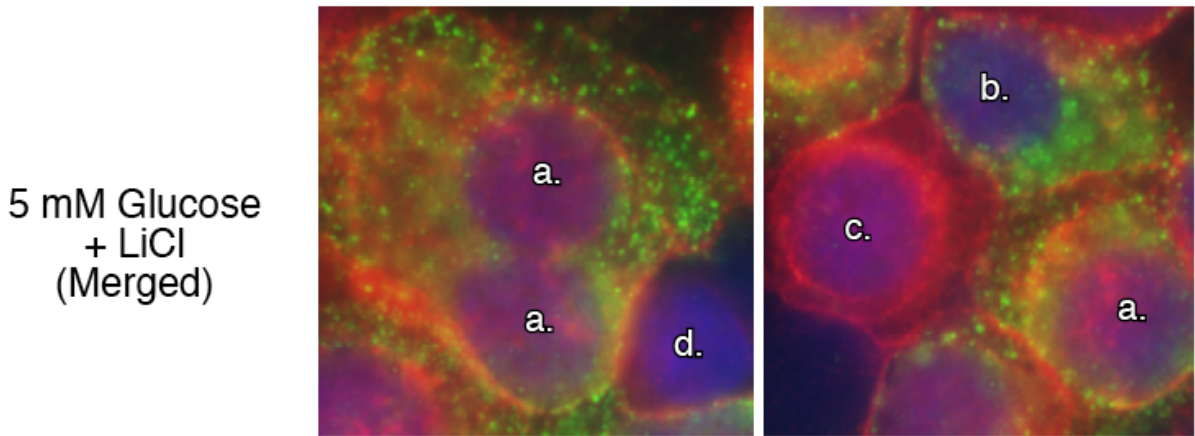

a. insulin positive (green cytoplasm)/nuclear $\beta$-catenin positive (purple nucleus)

b. insulin positive (green cytoplasm)/nuclear $\beta$-catenin negative (blue nucleus)

c. insulin negative/nuclear $\beta$-catenin positive (purple nucleus, red nuclear ring)

d. insulin negative/nuclear $\beta$-catenin negative (blue nucleus)

Fig. (9). Translocation of nuclear $\boldsymbol{\beta}$-catenin in human islets. (A) Fold increase in $\boldsymbol{\beta}$-catenin nuclear positive/insulin positive cells (with respect to $5 \mathrm{mM}$ glucose) as determined by immunohistochemical analysis. Data are the means \pm S.E. of $\mathrm{n}=3$ experiments. For each group per experiment, $\sim 5,000-6,000 \beta$-cells were counted. ${ }^{*} \mathrm{p}<0.05, * * \mathrm{p}<0.01$, and $* * * \mathrm{p}<0.001$ denote significant differences between the bracketed conditions. (B) Representative immunofluorescent images of dispersed human islets to demonstrate co-localization of cytoplasmic insulin and nuclear $\beta$-catenin used for quantitation in Fig. (9A). Reprinted with permission from ref. [57].

GSK-3 inhibition on mTOR activation, whereas the effect of the mTOR pathway on the GSK-3/ $\beta$-catenin pathway is significant in primary human islets.

\section{HUMAN ISLET INSULIN RESISTANCE}

In the course of these studies, we discovered that exogenous insulin was ineffective in stimulating DNA synthesis in human islets in contrast to rodent islets (Fig. 11A, B). GSK-3 inhibition with 1-Akp was employed as a positive control in this experimental design. Treatment of human islets with exogenous insulin also failed to result in
Akt (Fig. 11C) or GSK-3 phosphorylation (Fig. 11D). However, inhibiting mTOR with rapamycin, that relieves the negative feedback inhibition of insulin signaling, allows insulin to phosphorylate Akt, resulting in GSK-3 inhibition (Fig. 11C, D). However, this reversal of the negative feedback by rapamycin cannot be used as a therapeutic strategy to overcome insulin resistance since rapamycin inhibits $\beta$-catenin nuclear translocation (Fig. 9) and DNA synthesis (Fig. 2A). Overall, this suggests that a basal level of mTOR activation achieved at $5 \mathrm{mM}$ glucose, sufficiently engages feedback inhibition of the insulin signaling cascade 
A. Insulin Resistance In Vitro

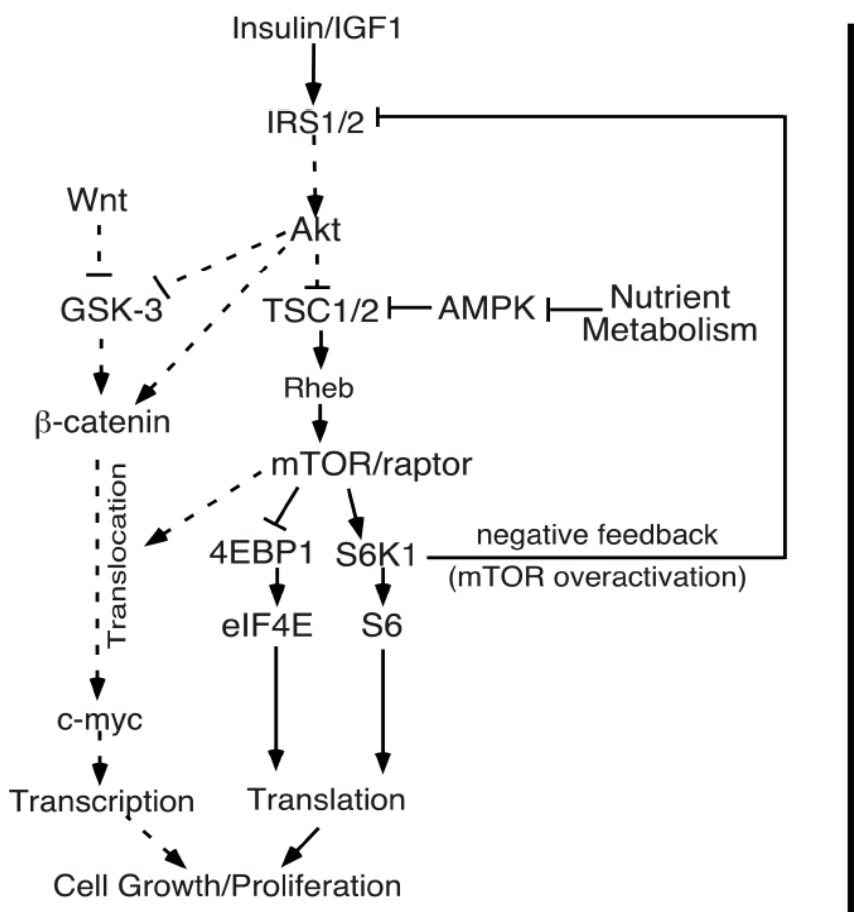

B. Circumvention of Human $\beta$-Cell Insulin Resistance by Direct GSK-3 Inhibition

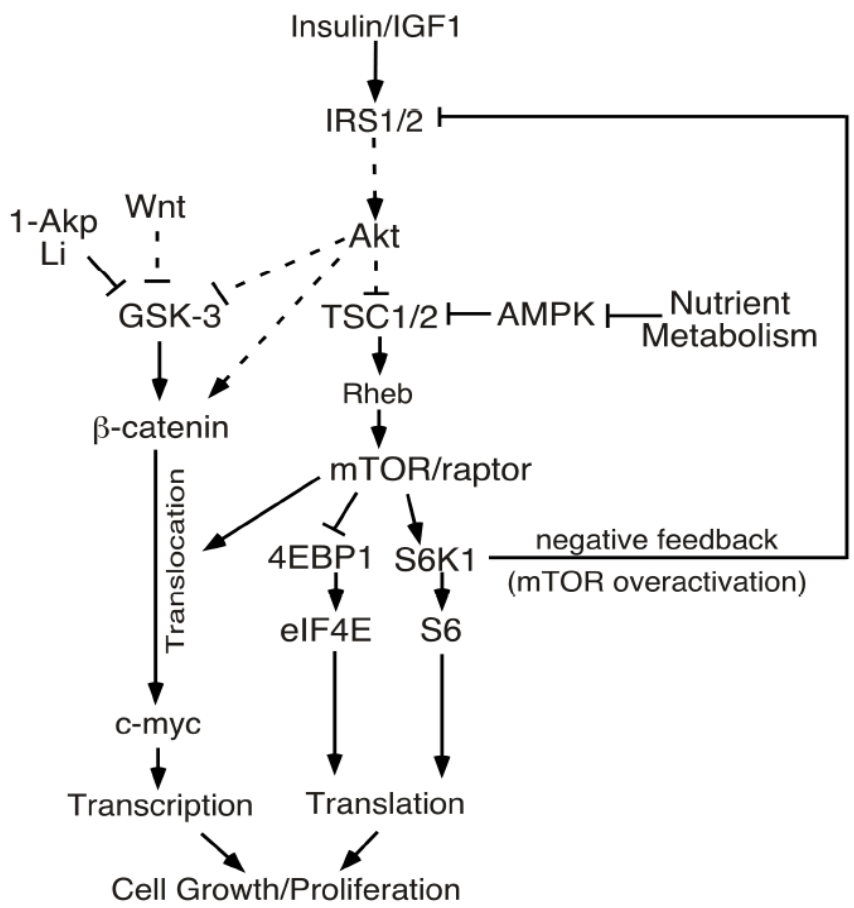

Fig. (10). Strategies to stimulate human $\beta$-cell proliferation by circumventing insulin resistance with direct GSK-3 inhibition in combination with nutrient activation of mTOR. (A) Human $\beta$-cell insulin resistance in vitro: Nutrient metabolism inhibits AMPK and TSC1/2, thus increasing mTOR and S6K1 activities. mTOR/S6K1 overactivation results in negative feedback and IRS1/2 degradation, blocking insulin signaling and the ability of Akt to inhibit GSK-3 and engage the Wnt signaling pathway. Under these insulin resistant conditions, GSK-3 remains active and $\beta$-catenin is not translocated to the nucleus. (B) Inhibition of GSK-3 by 1-Akp or LiCl results in activation of Wnt signaling and $\beta$-catenin nuclear translocation in vitro: $\mathrm{LiCl}$ or 1 -Akp directly inhibits GSK-3, thus circumventing insulin resistance as described above, resulting in mTOR-dependent $\beta$-catenin nuclear translocation. This strategy restores the regenerative processes of DNA synthesis, cell cycle progression and proliferation. Dotted lines indicate reduced signaling levels.

in human islets, resulting in insulin resistance, and may explain the need for direct inhibition of GSK-3 with therapeutic agents (see Fig. 10 legend). However, inhibition of GSK-3 alone in the absence of Akt activation may not be an optimal therapeutic strategy since activation of Akt signaling is necessary to promote cell survival, proliferation, $\beta$-cell differentiation and insulin biosynthesis [10]. We found that in almost all of the human islet isolations examined, nutrient or exogenous insulin treatments were ineffective at stimulating regenerative processes in the absence of GSK-3 inhibition. This occurred regardless of the donor's sex, age, BMI or the isolation center. It is unknown at this point, if this high level of $\beta$-cell insulin resistance is a result of the human islet isolation procedure, in vitro culture conditions, or exists in vivo as well. Importantly, this in vitro model of human islet insulin resistance may provide a unique opportunity to evaluate the efficacy of novel agents and /or strategies to increase insulin sensitivity in human islets in vitro.

\section{SUMMARY}

In this perspective, we have focused on the development of therapeutic strategies to increase the proliferative potential of adult human $\beta$-cells. A feasible and available strategy derived from these studies is described schematically in Fig. (10). We have demonstrated that targeting the Wnt/GSK-
3/B-catenin signaling pathway using pharmacological agents in combination with nutrient activation of the mTOR pathway is critical for substantially increasing DNA synthesis, cell cycle progression and human $\beta$-cell proliferation in vitro. Nutrient signaling through the mTOR pathway alone was sufficient to increase regenerative processes in rodent islets, whereas nutrients were rarely effective in human islets. This highlights a significant difference in the activation requirements of these pathways between human and rodent islets in vitro. In human $\beta$-cells, we also found that the nuclear translocation of $\beta$-catenin in response to GSK-3 inhibition was rapamycin sensitive, suggesting a significant role for mTOR in facilitating translocation. This crosstalk involving mTOR-mediated $\beta$ catenin nuclear translocation is believed to be responsible, in part, for the inhibition of these regenerative processes by rapamycin. Another significant difference between human and rodent islets is that human islets exhibited a relatively high level of insulin resistance in comparison to rodent islets. Human islet insulin resistance is believed to be due to mTOR-mediated negative feedback inhibition of the insulin signaling pathway, since rapamycin restored Akt and GSK-3 phosphorylation. This insulin resistance may be responsible for the requirement to directly inhibit GSK-3 by pharmacological agents in order to engage the Wnt signaling pathway. Insulin resistance also explains the inability of 
A.

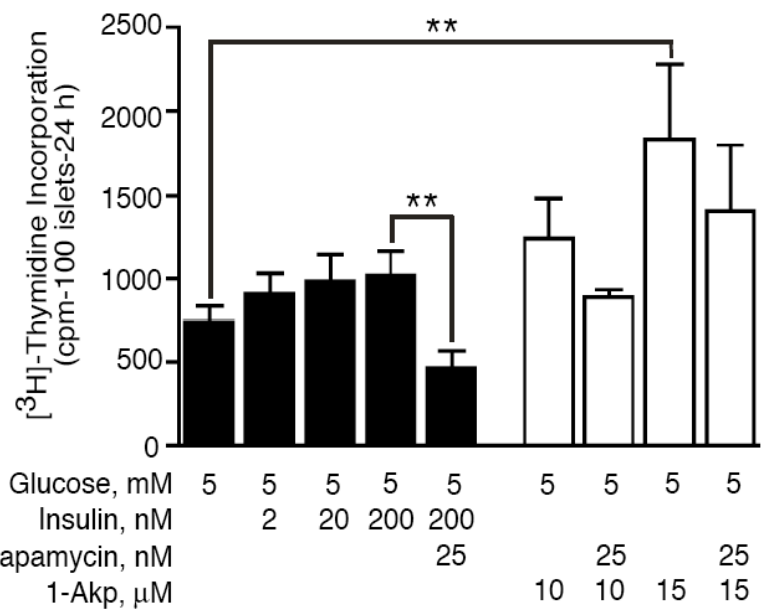

4 Day Treatment Conditions
B.

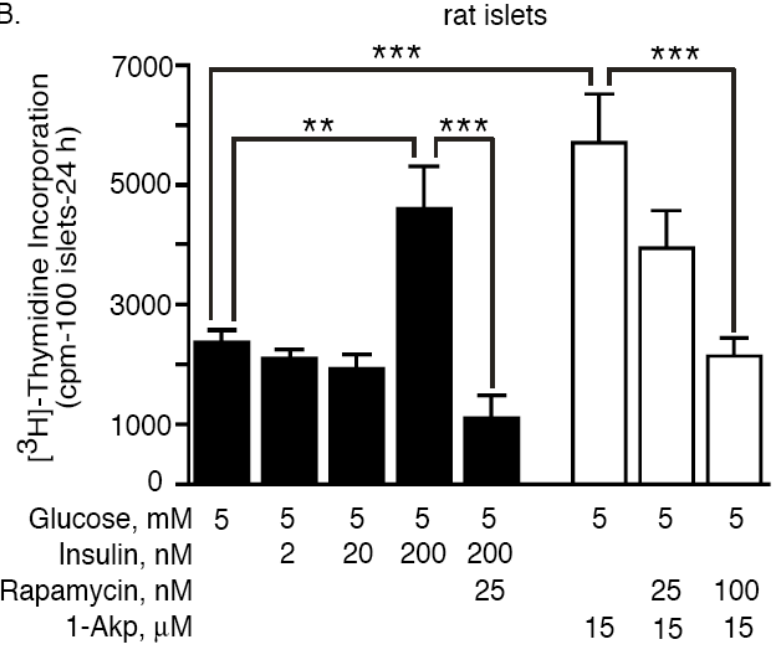

4 Day Treatment Conditions

Human islets

C.

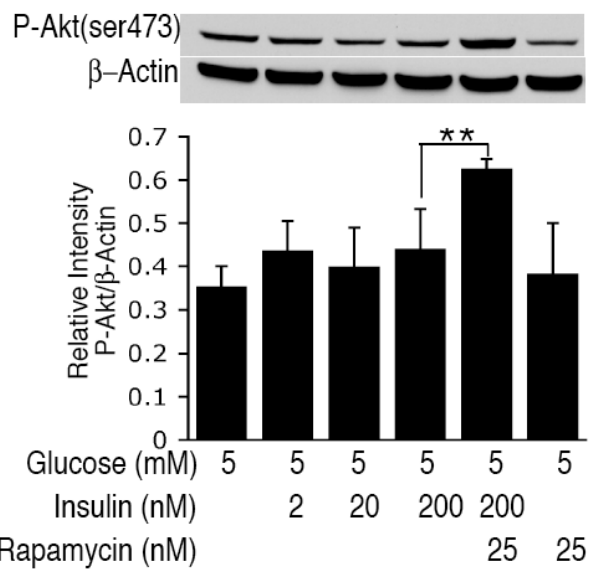

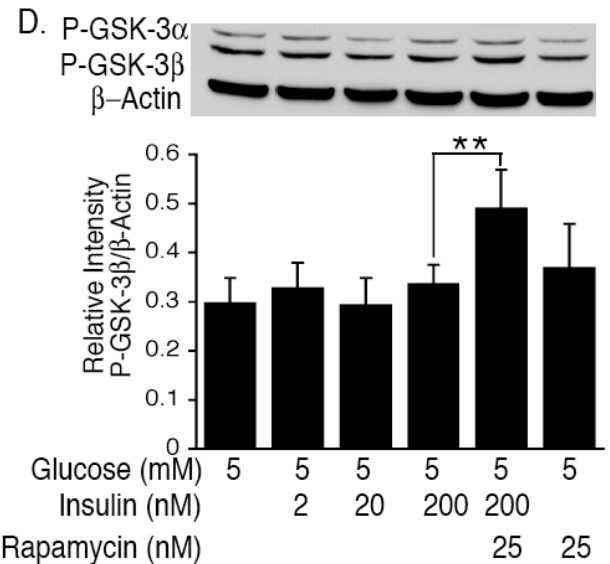

Fig. (11). Effects of exogenous insulin on the insulin signaling pathway. Human (A) or rat islets (B) (100) were cultured for 4 days in CMRL as indicated and ${ }^{3} \mathrm{H}$-thymidine incorporation was determined during the final $24 \mathrm{~h}$. Data are the means \pm SE of $n=3$ experiments with triplicate samples in each experiment. ${ }^{* *} \mathrm{p}<0.01$ and $* * * p<0.001$ denote significant differences between the bracketed conditions. (C and $\left.\mathbf{D}\right)$ Human islets (100) were treated for $30 \mathrm{~min}$ in CMRL as indicated and processed for Western Blotting. $\beta$-Actin was used as a protein loading control. Data are the means \pm S.E. of $n=3$ (C) or 2 (D) experiments. ${ }^{*} \mathrm{p}<0.01$ indicates significant difference between the bracketed conditions. Reprinted with permission from ref. [57].

exogenous insulin to exert effects on these regenerative processes. Although human islets displayed a normal insulin secretory function following our therapeutic strategies designed to enhance growth and proliferation, a loss of stored insulin content was observed after the 4-day culture period independent of all treatment conditions [57]. In contrast, rodent islets retained their insulin content over this incubation period. These significant differences: a lack of a nutrient response, a requirement for direct GSK-3 inhibition, insulin resistance, and the loss of insulin content in human islets, underscores the importance of conducting studies with human islets due to the uncertainty of the translational relevance of rodent islets and $\beta$-cell lines.

Overall, these studies indicate that appropriate regulation of mTOR by nutrients and Wnt/GSK-3/ $\beta$-catenin through direct inhibition of GSK-3 with $\mathrm{LiCl}$ or 1-Akp enhances human $\beta$-cell proliferation in vitro. In addition, our data demonstrate that Exenatide treatment of human and rat islets result in significant increases in cell cycle progression in a glucose-dependent manner. Based on our data and others [15], we conclude that the effects of Exenatide on human and rat islets are mediated through both mTOR and Wnt/GSK-3/ $\beta$-catenin pathways. Our future goal will be to develop therapeutic approaches and novel agents that will reduce insulin resistance due to mTOR overactivation and restore insulin signaling and Akt phosphorylation in response to insulin or IGFs, while retaining a necessary level of mTOR activation in human islets. These therapeutic strategies are designed to unmask the proliferative capacity, function and survival of adult human islets to decrease the number of islets required for transplantations in T1DM and to extend the ability of human $\beta$-cells to compensate in the face of increased peripheral insulin resistance in T2DM. 


\section{ACKNOWLEDGMENTS}

This publication was made possible by support from the National Institutes of Health Grants DK006181 (MLM) and DK07296 (MLM), Washington University Diabetes Research and Training Center DK020579 (Immunoassay Core and Morphology and Bioimaging Core, Histology and Islet Subcores), the American Diabetes Association Grants 7-04-MN-32 (MLM), 7-09-MN-30 (MLM), ADA and Takeda Pharmaceuticals Mentor Based Minority Postdoctoral Fellowship Award (MLM), and a grant from the Amylin-Lilly-Alliance (MLM). Exenatide provided by Amylin (San Diego, CA). Human islets were obtained from $\mathrm{NIH}$ sponsored ICR Basic Science Islet Distribution Program Centers and the JDRF Human Islet Distribution Program. Its contents are solely the responsibility of the authors.

\section{CONFLICT OF INTEREST}

Authors received a grant (09/2005-9/2006) from the Amylin-Lilly-Alliance (MLM). Exenatide provided by Amylin (San Diego, CA). Authors declare no current conflict of interest with any financial institution.

\section{REFERENCES}

[1] Buteau J. GLP-1 receptor signaling: effects on pancreatic beta-cell proliferation and survival. Diabetes Metab 2008; 34: S73-7.

[2] Kukreja A, Maclaren NK. Autoimmunity and diabetes. J Clin Endocrinol Metab 1999; 84: 4371-8.

[3] DeFronzo RA. Insulin resistance: a multifaceted syndrome responsible for NIDDM, obesity, hypertension, dyslipidaemia and atherosclerosis. Neth J Med 1997; 50: 191-7.

[4] Wajchenberg BL. Beta-cell failure in diabetes and preservation by clinical treatment. Endocr Rev 2007; 28: 187-218.

[5] Park S, Dong X, Fisher TL, et al. Exendin-4 uses Irs2 signaling to mediate pancreatic beta cell growth and function. J Biol Chem 2006; 281: 1159-68

[6] Movassat J, Beattie GM, Lopez AD, Hayek A. Exendin 4 upregulates expression of PDX 1 and hastens differentiation and maturation of human fetal pancreatic cells. J Clin Endocrinol Metab 2002; 87: 4775-81

[7] Farilla L, Bulotta A Hirshberg B, et al. Glucagon-like peptide 1 inhibits cell apoptosis and improves glucose responsiveness of freshly isolated human islets. Endocrinology 2003; 141: 5149-58.

[8] Drucker DJ. Glucagon-like peptide-1 and the islet b-cell: Augmentation of cell proliferation and inhibition of apoptosis. Endocrinology 2003; 144: 5145-48.

[9] Natalicchio A, De Stefano F, Orlando MR et al. Exendin-4 Prevents c-Jun N-Terminal Protein Kinase Activation by Tumor Necrosis Factor- $\{\alpha\}$ (TNF $\{$ alpha $\}$ ) and inhibits TNF $\{$ alpha $\}-$ Induced Apoptosis in Insulin-Secreting Cells. Endocrinology 2010; [Epub ahead of print].

[10] Rhodes CJ. Type 2 diabetes-a matter of beta-cell life and death? Science 2005; 307: 380-4.

[11] Finegood DT, Scaglia L, Bonner-Weir S. Dynamics of beta-cell mass in the growing rat pancreas. Estimation with a simple mathematical model. Diabetes 1995; 44: 249-56.

[12] Dickson LM, Rhodes CJ. Pancreatic beta-cell growth and survival in the onset of type 2 diabetes: a role for protein kinase B in the Akt? Am J Physiol Endocrinol Metab 2004; 287: E192-8.

[13] Heit JJ, Karnik SK, Kim SK. Intrinsic regulators of pancreatic betacell proliferation. Annu Rev Cell Dev Biol 2006; 22: 311-38.

[14] Crabtree GR, Olson EN. NFAT signaling: choreographing the social lives of cells. Cell 2002; 109(Suppl): S67-79.

[15] Liu Z, Habener JF. Glucagon-like peptide-1 activation of TCF7L2dependent Wnt signaling enhances pancreatic beta cell proliferation. J Biol Chem 2008; 283: 8723-35.

[16] Friedrichsen BN, Richter HE, Hansen JA, et al. Signal transducer and activator of transcription 5 activation is sufficient to drive transcriptional induction of cyclin D2 gene and proliferation of rat pancreatic beta-cells. Mol Endocrinol 2003; 17: 945-58.
[17] Vasavada RC, Garcia-Ocaña A, Zawalich WS, et al. Targeted expression of placental lactogen in the beta cells of transgenic mice results in beta cell proliferation, islet mass augmentation, and hypoglycemia. J Biol Chem 2000; 275: 15399-406.

[18] You H, Laychock SG. Atrial natriuretic peptide promotes pancreatic islet beta-cell growth and Akt/Foxola/cyclin D2 signaling. Endocrinology 2009; 150: 5455-65.

[19] Cozar-Castellano I, Haught M, Stewart AF. The cell cycle inhibitory protein $\mathrm{p} 21 \mathrm{cip}$ is not essential for maintaining beta-cell cycle arrest or beta-cell function in vivo. Diabetes 2006; 55(12): 3271-8.

[20] Liu Y, Mziaut H, Ivanova A, Solimena M. Beta-Cells at the crossroads: choosing between insulin granule production and proliferation. Diabetes Obes Metab 2009; 11: 54-64.

[21] Steil GM, Trivedi N, Jonas JC, et al. Adaptation of beta-cell mass to substrate oversupply: enhanced function with normal gene expression. Am J Physiol Endocrinol Metab 2001; 280: E788-96.

[22] Lipsett M, Finegood DT. Beta-cell neogenesis during prolonged hyperglycemia in rats. Diabetes 2002; 51: 1834-41.

[23] Paris M, Bernard-Kargar C, Berthault MF, et al. Specific and combined effects of insulin and glucose on functional pancreatic beta-cell mass in vivo in adult rats. Endocrinology 2003; 144: 2717-27.

[24] Dor Y, Brown J, Martinez OI, Melton DA. Adult pancreatic betacells are formed by self-duplication rather than stem-cell differentiation. Nature 2004; 429: 41-6.

[25] Dor Y. Beta-Cell proliferation is the major source of new pancreatic beta cells. Nat Clin Pract Endocrinol Metab 2006; 2: 242-3.

[26] Teta M, Long SY, Wartschow LM, et al. Very slow turnover of beta-cells in aged adult mice. Diabetes 2005; 54: 2557-67.

[27] Nir T, Melton DA, Dor Y. Recovery from diabetes in mice by beta cell regeneration. J Clin Invest 2007; 117: 2553-61.

[28] Teta M, Rankin MM, Long SY, et al. Growth and regeneration of adult beta cells does not involve specialized progenitors. Dev Cell 2007; 12: 817-26.

[29] Cutler NS, Heitman J, Cardenas ME. TOR kinase homologs function in a signal transduction pathway that is conserved from yeast to mammals. Mol Cell Endocrinol 1999; 155: 135-42.

[30] Martin KA, Blenis J. Coordinate regulation of translation by the PI 3-kinase and mTOR pathways. Adv Cancer Res 2002; 86: 1-39.

[31] Ma XM, Blenis J. Molecular mechanisms of mTOR-mediated translational control. Nat Rev Mol Cell Biol 2009; 10: 307-18.

[32] Hay N, Sonenberg N. Upstream and downstream of mTOR. Genes Dev 2004; 18: 1926-45.

[33] McDaniel ML, Marshall CA, Pappan KL, et al. Metabolic and autocrine regulation of the mammalian target of rapamycin by pancreatic beta-cells. Diabetes 2002; 51:2877-85.

[34] Bhaskar PT, Hay N. The two TORCs and Akt. Dev Cell 2007; 12 487-502.

[35] Laplante M, Sabatini DM. mTOR signaling at a glance. J Cell Sci 2009; 122: 3589-3594.

[36] Dann SG, Selvaraj A, Thomas G. mTOR Complex1-S6K1 signaling: at the crossroads of obesity, diabetes and cancer. Trends Mol Med 2007; 13: 252-9.

[37] Wullschleger S, Loewith R, Hall MN. TOR signaling in growth and metabolism. Cell 2006; 124: 471-84.

[38] Jacinto E, Loewith R, Schmidt A, et al. Mammalian TOR complex 2 controls the actin cytoskeleton and is rapamycin insensitive. Nat Cell Biol 2004; 6: 1122-28.

[39] Sarbassov DD, Ali SM, Kim DH, et al. Rictor, a novel binding partner of mTOR, defines a rapamycin-insensitive and raptorindependent pathway that regulates the cytoskeleton. Curr Biol 2004; 14: 1296-302.

[40] Alessi DR, Pearce LR, García-Martínez JM. New insights into mTOR signaling: mTORC2 and beyond. Sci Signal 2009; 2: pe27.

[41] Harrington LS, Findlay GM, Lamb RF. Restraining PI3K: mTOR signalling goes back to the membrane. Trends Biochem Sci 2005; 30: $35-42$.

[42] Marks AR. Rapamycin: Signaling in vascular smooth muscle. Transpl Proc 2003; 35(Supp. 3A): 231S-233S.

[43] Patel J, Wang X, Proud CG. Glucose exerts a permissive effect on the regulation of the initiation factor $4 \mathrm{E}$ binding protein $4 \mathrm{E}-\mathrm{BP} 1$. Biochem J 2001; 358: 497-503.

[44] Xu G, Marshall CA, Lin TA, et al. Insulin mediates glucosestimulated phosphorylation of PHAS-I by pancreatic beta cells. An 
insulin-receptor mechanism for autoregulation of protein synthesis by translation. J Biol Chem 1998; 273: 4485-91.

[45] Xu G, Kwon G, Marshall CA, et al. Branched-chain amino acids are essential in the regulation of PHAS-I and p70 S6 kinase by pancreatic beta-cells. A possible role in protein translation and mitogenic signaling. J Biol Chem 1998; 273: 28178-84.

[46] Hara K, Yonezawa K, Weng QP, et al. Amino acid sufficiency and mTOR regulate p70 S6 kinase and eIF-4E BP1 through a common effector mechanism. J Biol Chem 1998; 273(23): 14484-94. Erratum in: J Biol Chem 1998; 273: 22160.

[47] Patti ME, Brambilla E, Luzi L, Landaker EJ, Kahn CR. Bidirectional modulation of insulin action by amino acids. J Clin Invest 1998; 101: 1519-29.

[48] Anthony JC, Anthony TG, Kimball SR, Jefferson LS. Signaling pathways involved in translational control of protein synthesis in skeletal muscle by leucine. J Nutr 2001; 131: 856S-860S.

[49] Xu G, Kwon G, Cruz WS, et al. Metabolic regulation by leucine of translation initiation through the mTOR-signaling pathway by pancreatic beta-cells. Diabetes 2001; 50: 353-60.

[50] Gleason CE, Lu D, Witters LA, Newgard CB, Birnbaum MJ. The role of AMPK and mTOR in nutrient sensing in pancreatic $\beta$-cells. J Biol Chem 2007; 282: 10341-51.

[51] Greiwe JS, Kwon G, McDaniel ML, et al. Leucine and insulin activate p70 S6 kinase through different pathways in human skeletal muscle. Am J Physiol Endocrinol Metab 2001; 281: E46671 .

[52] Kwon G, Marshall CA, Pappan KL, et al. Signaling elements involved in the metabolic regulation of mTOR by nutrients, incretins, and growth factors in islets. Diabetes 2004; 53: S225-32.

[53] Namkung Y, Skrypnyk N, Jeong MJ, et al. Requirement for the Ltype $\mathrm{Ca}^{2+}$ channel $\alpha 1 \mathrm{D}$ subunit in postnatal pancreatic $\beta$ cell generation. J Clin Invest 2001; 108: 1015-22.

[54] Conus NM, Hemmings BA, Pearson RB. Differential regulation by calcium reveals distinct signaling requirements for the activation of Akt and p70S6k. J Biol Chem 1998; 273: 4776-82.

[55] Hannan KM, Thomas G, Pearson RB. Activation of S6K1 (p70 ribosomal protein S6 kinase 1) requires an initial calciumdependent priming event involving formation of a high-molecularmass signalling complex. Biochem J 2003; 370: 469-77.

[56] Kwon G, Marshall CA, Liu H, et al. Glucose-stimulated DNA synthesis through mammalian target of rapamycin (mTOR) is regulated by KATP channels: effects on cell cycle progression in rodent islets. J Biol Chem 2006; 281: 3261-7.

[57] Liu H, Remedi MS, Pappan KL, et al. Glycogen synthase kinase-3 and mammalian target of rapamycin pathways contribute to DNA synthesis, cell cycle progression, and proliferation in human islets. Diabetes 2009; 58: 663-72.

[58] Sjoholm A, Welsh N, Hellerstrom C. Lithium increases DNA replication, polyamine content, and insulin secretion by rat pancreatic $\beta$-cells. Am J Physiol Cell Physiol 1992; 262: C391C395.

[59] Moon RT, Kohn AD, De Ferrari GV, et al. WNT and beta-catenin signalling: diseases and therapies. Nat Rev Genet 2004; 5: 689-99.

[60] Jope RS, Roh MS. Glycogen synthase kinase-3 (GSK3) in psychiatric diseases and therapeutic interventions. Curr Drug Targets 2006; 7: 1421-34

[61] Rulifson IC, Karnik SK, Heiser PW, et al. Wnt signaling regulates pancreatic $\beta$-cell proliferation. Proc Natl Acad Sci USA 2007; 104 : 6247-6252.

[62] Desbois-Mouthon C, Cadoret A, Blivet-Van Eggelpoël MJ, et al. Insulin and IGF-1 stimulate the beta-catenin pathway through two signalling cascades involving GSK-3beta inhibition and Ras activation. Oncogene 2001; 20: 252-9.
[63] Satyamoorthy K, Li G, Vaidya B, et al. Insulin-like growth factor-1 induces survival and growth of biologically early melanoma cells through both the mitogen-activated protein kinase and beta-catenin pathways. Cancer Res 2001; 61: 7318-24.

[64] Verras M, Sun Z. Beta-catenin is involved in insulin-like growth factor 1-mediated transactivation of the androgen receptor. Mol Endocrinol 2005; 19: 391-8.

[65] He TC, Sparks AB, Rago C, et al. Identification of c-MYC as a target of the APC pathway. Science 1998; 281: 1509-12.

[66] Shtutman M, Zhurinsky J, Simcha I, et al. The cyclin D1 gene is a target of the beta-catenin/LEF-1 pathway. Proc Natl Acad Sci USA 1999; 96: 5522-7.

[67] Klein PS, Melton DA. A molecular mechanism for the effect of lithium on development. Proc Natl Acad Sci U S A 1996; 93: 84559.

[68] Stambolic V, Ruel L, Woodgett JR. Lithium inhibits glycogen synthase kinase- 3 activity and mimics wingless signalling in intact cells. Curr Biol 1996; 6: 1664-8.

[69] Ni Z, Anini Y, Fang X, et al. Transcriptional activation of the proglucagon gene by lithium and beta-catenin in intestinal endocrine L cells. J Biol Chem 2003; 278: 1380-7.

[70] Cohen P, Goedert M. GSK3 inhibitors: development and therapeutic potential. Nat Rev Drug Discov 2004; 3: 479-87.

[71] Liu Z, Tanabe K, Bernal-Mizrachi E, et al. Mice with beta cell overexpression of glycogen synthase kinase-3beta have reduced beta cell mass and proliferation. Diabetologia 2008; 51: 623-31.

[72] Mussmann R, Geese M, Harder F, et al. Inhibition of GSK3 promotes replication and survival of pancreatic beta cells. J Biol Chem 2007; 282: 12030-7.

[73] $\mathrm{Xu}$ G, Stoffers DA, Habener JF, et al. Exendin-4 stimulates both beta-cell replication and neogenesis, resulting in increased beta-cell mass and improved glucose tolerance in diabetic rats. Diabetes 1999; 48: 2270-6.

[74] Egan JM, Bulotta A, Hui H, et al. GLP-1 receptor agonists are growth and differentiation factors for pancreatic islet beta cells. Diabetes Metab Res Rev 2003; 19: 115-23.

[75] List JF, Habener JF. Glucagon-like peptide 1 agonists and the development and growth of pancreatic beta-cells. Am J Physiol Endocrinol Metab 2004; 286: E875-81.

[76] Parnaud G, Bosco D, Berney T, et al. Proliferation of sorted human and rat beta cells. Diabetalogia 2008; 51: 91-100.

[77] Meier JJ, Butler AE, Saisho Y, et al. $\beta$-cell replication is the primary mechanism subserving the postnatal expansion of $\beta$-cell mass in humans. Diabetes 2008; 57: 1584-94.

[78] Meier JJ, Kohler CU, Alkhatib B, et al. $\beta$-cell development and turnover during prenatal life in humans. Eur J Endocrinol 2010; 162: 559-68.

[79] Butler AE, Janson J, Bonner-Weir S, Ritzel R, Rizza RA, Butler PC. Beta-cell deficit and increased beta-cell apoptosis in humans with type 2 diabetes. Diabetes 2003; 52: 102-10.

[80] Butler AE, Janson J, Soeller WC, Butler PC. Increased beta-cell apoptosis prevents adaptive increase in beta-cell mass in mouse model of type 2 diabetes: evidence for role of islet amyloid formation rather than direct action of amyloid. Diabetes 2003; 52 : 2204-314.

[81] Ouziel-Yahalom L, Zalzman M, Anker-Kitai L, et al. Expansion and redifferentiation of adult human pancreatic islet cells. Biochem Biophys Res Commun 2006; 341: 291-8.

[82] Inoki K, Ouyang H, Zhu T, et al. TSC2 integrates Wnt and energy signals via a coordinated phosphorylation by AMPK and GSK3 to regulate cell growth. Cell 2006; 126: 955-68.

[83] Jin T, Fantus IG, Sun J. Wnt and beyond Wnt: multiple mechanisms control the transcriptional property of beta-catenin. Cell Signal 2008; 20: 1697-704.

This is an open access article licensed under the terms of the Creative Commons Attribution Non-Commercial License (http://creativecommons.org/licenses/by$\mathrm{nc} / 3.0 /$ ) which permits unrestricted, non-commercial use, distribution and reproduction in any medium, provided the work is properly cited. 